\title{
The Treatment of Acid Mine Drainage Using Vertically Flowing Wetland: Insights into the Fate of Chemical Species
}

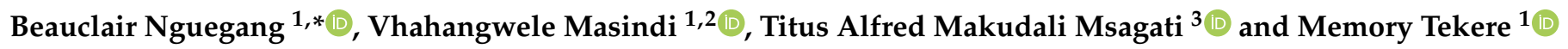 \\ 1 Department of Environmental Science, College of Agriculture and Environmental Sciences (CAES), \\ University of South Africa (UNISA), P.O. Box X9, Florida 1710, South Africa; \\ masindivhahangwele@gmail.com (V.M.); tekerm@unisa.ac.za (M.T.) \\ 2 Magalies Water (MW), Scientific Services (SS), Research \& Development (R\&D) Division, Erf 3475, \\ Stoffberg Street, Brits 0250, South Africa \\ 3 Institute of Nanotechnology and Water Sustainability, College of Science, Engineering and Technology (CSET), \\ University of South Africa (UNISA), P.O. Box 392, Florida 1710, South Africa; msagatam@unisa.ac.za \\ * Correspondence: demenvc@gmail.com
}

check for updates

Citation: Nguegang, B.; Masindi, V.; Msagati, T.A.M.; Tekere, M. The Treatment of Acid Mine Drainage Using Vertically Flowing Wetland: Insights into the Fate of Chemical Species. Minerals 2021, 11, 477. https://doi.org/10.3390/min11050477

Academic Editor: Carlito Tabelin

Received: 26 February 2021

Accepted: 23 April 2021

Published: 30 April 2021

Publisher's Note: MDPI stays neutral with regard to jurisdictional claims in published maps and institutional affiliations.

Copyright: (c) 2021 by the authors. Licensee MDPI, Basel, Switzerland. This article is an open access article distributed under the terms and conditions of the Creative Commons Attribution (CC BY) license (https:/ / creativecommons.org/licenses/by/ $4.0 /)$.

\begin{abstract}
In this study, the treatment of acid mine drainage (AMD) using vertically flowing wetland was explored. The wetland was enriched with Vetiveria zizanioides as a decontaminating media and soil as the substrate. Water was percolated through the substrate and the throughput samples were collected and characterized every five days for a period of 30 days. The obtained results revealed a tolerant index of 1.03 for Vetiveria zizanioides, and a net reduction of metals and sulfate. The removal efficacy of chemical species was observed to obey the following order: Fe $(71.25 \%)>\mathrm{Zn}(70.40 \%)$ $>\mathrm{Mn}(62 \%)>\mathrm{Al}(56.68 \%)>\mathrm{SO}_{4}{ }^{2-}(55.18 \%)>\mathrm{Ni}(35 \%)>\mathrm{Cu}(18.83 \%)$. The removal of chemical species was further aided by the used substrate, and this could be attributed to the accumulation of chemical species on the soil through precipitation, adsorption, and phyto-retention. As such, it could be deduced that the substrate plays a significant role in the removal of metals, while the grass and external factors accounted for the rest of the chemical species attenuation. The translocation assessment revealed that the distribution of chemical species was observed to be predominant in the roots, except manganese, which was transferred in the shoot $(67 \%)$. The XRF, XRD, FTIR, and SEM-EDS analysis revealed the presence of AMD chemical species in the substrate and the grass components, hence confirming that the plants are playing a huge role in the removal of contaminants from AMD. The PH REdox EQuilibrium (in C language) (PHREEQC) geochemical model confirm that metals existed as di-and-trivalent complexes in AMD. Lastly, available metals were precipitated as metals hydroxides and oxy-hydrosulfates by the substrate. In light of the obtained results, vertically flowing wetland could be used for the passive treatment of AMD, and it will play a huge role in active and abandoned mines. However, prolonged assessment should be undertaken to understand its performance over a notable period of time.
\end{abstract}

Keywords: acid mine drainage; vertically flowing wetland; treatment; phytoremediation; Vetiveria zizanioides

\section{Introduction}

Over many decades, the mining of gold and coal has played an indispensable role in the economy of any given country. The latter has been widely used for its high colorific value for power generation, while gold has been used for jewelry [1]. Despite their enormous socio-economic benefits, mining has been associated with numerous environmental problems, such as land destruction and the generation of acid mine drainage (AMD), among others [2,3]. Due to the nature and magnitude of its ecological impacts, AMD has been a topical issue that has been troubling the mining industry over the years [4,5]. In particular, during the mining of coal and gold, the associated sulfide-bearing minerals such as pyrite and arsenopyrite which are embedded in the surrounding geology and stratas get 
exposed to oxidizing conditions $[1,6,7]$ During rainfall and underground leakages, sulfide minerals come into contact with water and oxygen, leading to the formation of highly acidic mine effluent known as acid mine drainage (AMD) [8]. With the use of pyrite as an example, the formation of acid mine drainage (AMD) could be explained by the following equation (Equation (1)) [1]:

$$
4 \mathrm{FeS}_{2}+15 \mathrm{O}_{2}+14 \mathrm{H}_{2} \mathrm{O} \stackrel{\text { microorganisms }}{\longrightarrow} 4 \mathrm{Fe}(\mathrm{OH})_{3}+8 \mathrm{SO}_{4}^{2-}+16 \mathrm{H}^{+}
$$

This reaction is also mediated by microorganisms [9]. The acidity in AMD promotes the leaching of heavy metals and metalloids from the surrounding geology [10-12]. According to the literature, $\mathrm{AMD}$ comprises $\mathrm{Al}, \mathrm{Fe}, \mathrm{Mn}$, and $\mathrm{SO}_{4}$ as major elements, and traces of $\mathrm{Cu}, \mathrm{Zn}, \mathrm{Ni}, \mathrm{Pb}, \mathrm{Cr}, \mathrm{As}$, and radionuclides, among others $[1,5,13,14]$. These chemical species exceed the recommended limits for discharge as stipulated by the World Health Organization (WHO) [15]. As such, the discharge of AMD may lead to the degradation of receiving ecological systems and compartments [5], hence affecting the integrity of the ecosystem and its ability to support life $[3,6,8]$. According to ecotoxicological and epidemiological reports, constituents embodied in AMD can pose various carcinogenic, mutagenic, and teratogenic conditions to living organisms on exposure $[1,3,16,17]$. As such, stringent regulatory frameworks require AMD effluent to be treated before it can be discharged into different receiving environments [18,19].

In light of the above, various technologies have been developed for the treatment of AMD, which include both active and passive treatment systems [20,21]. Specifically, active treatment technologies include ion exchange [22], adsorption [23], filtration [24,25], neutralization [15,26], and crystallization [27], whereas passive treatment methods include constructed wetlands [28], phytoremediation [29-31] bio-sorption [32], permeable reactive barriers (PRB) [33], sulfate-reducing bioreactors [34], anoxic limestone drains [35], and slag leach bed [36]. These technologies have their advantages and disadvantages; the active treatment technologies require energy and frequent chemical inputs, whereas passive treatment systems are the opposite. Furthermore, active treatment technologies are not cost effective and require constant maintenance and skilled staff among others; furthermore, they are grossly deemed not environmentally friendly since they generate a considerable volume of sludge, which in turn leads to a new environmental problem to be solved due to secondary pollution from the highly mineralized and heterogeneous sludge $[24,34,37]$. Therefore, they cannot be considered a long-term solution for AMD treatment. Following the persisting environmental impacts of AMD and the limitation of existing technologies, there is a need to investigate, develop, and implement an environmentally friendly treatment technology for the removal of contaminants from AMD. Phytoremediation has been reported as the most eco-friendly way of attenuating contaminants from different spheres of the environment, and it plays a crucial role in the reduction of heavy metals and sulfates from AMD $[30,38]$. Phytoremediation is an in situ intervention and there is no need for transportation and off-site processing cost except for floral plantations. In addition, the phytoremediation process prevents metals from leaching due to high metals being retained intensively post extraction. The metals will then be stored in the plant biomass or released in volatile form into the atmosphere through a process known as phytovolatilization. To this end, pollutants are removed by a wetland via (i) phyto-extraction by the plants roots [39], (ii) phyto-stimulation, which is the breaking down of organics contaminants in plant root zone by microbial activity [40], (iii) phyto-degradation, which is the metabolization of contaminants in plant tissue to less toxic level [41], and lastly, (iv) the phyto-stabilization process, which basically entails the de-mobilization of heavy metals in soil by plant roots [42].

Noting that plants play an important role in the bioremediation, the selection of plant species to be used is crucial since they will improve the overall pollutants removal process considering that metals accumulated by plants are stored in their biomass or released as volatile form into the atmosphere through the phyto-volatilization process. Various studies 
have revealed that Vetiveria zizanioides $(V Z)$ is tolerant to very harsh environments, such as the acidic and metalliferous conditions in AMD. Furthermore, it grows well in aquatic and terrestrial environments [31,43], is tolerant to salinity conditions, grows well in all seasons, and is tolerant to heavy metals and others pollutants. However, its use with the substrate and on a vertically flowing modality has merely been considered, specifically considering AMD. The vertical flow allows for maximum reaction and interaction between the substrate and plants so as to enhance the attenuation of chemical constituents in relation to horizontal flows. To the best of our knowledge, the subsurface vertical flow constructed wetlands (SSVF-CWs) has never been explored for AMD treatment using VZ with the substrate. Engineering-wise, the SSVF-CW is the type of wetland where water is poured onto a surface and percolates through the soil vertically to the bottom of the cell, where it is drained horizontally to the outlet, where it is collected and characterized. Furthermore, SSVF-CWs are characterized by an abundance of oxygen and substrate pores which are intermittently filled and drained with water, thereby creating an aerobic environment for metals precipitation, facilitation of certain biochemical reactions, and aerobic decomposition $[44,45]$. In light of the above, SSVF-CWs have demonstrated their abilities to remove pollutants and other contaminants from waste water and are, therefore, considered as viable low-cost replacements of traditional methods which are expensive, require skilled personal, and generate waste that requires additional treatment $[45,46]$. The ultimate goal of this study is to highlight the accumulation and translocation of chemical species from contaminated water to the plants. The impact of the used substrate will also be evaluated.

\section{Materials and Methods}

\subsection{Acquisition of Reagents, Substrate, and Plants}

All reagents used in this study were of analytical grade (AG) and were obtained from Merck, South Africa. Prior to the construction of subsurface vertical flow constructed wetland (SSVF-CW), shoots of Vetiveria zizanioides were purchased from the NANDADRAM ECOVILLAGE farm in Kwa-Zulu Natal, South Africa and transported to the University of South Africa's sciences campus in Florida, Johannesburg. Once on campus, the shoots of Vetiveria zizanioides were submerged under potable fresh water for two weeks in order to allow the news seeds to germinate. After that, seedlings of Vetiveria zizanioides were transferred into small pots containing organic matter used as wetland substrate (soil purchased from garden world Johannesburg, RSA) as growing medium. Plants were allowed to grow naturally without the addition of nutrients and were monitored and watered daily.

\subsection{Sampling and Characterization of AMD Water}

Acid mine drainage (AMD) water used in this study was collected at the Gold mine in Krugersdorp, Gauteng, South Africa (Latitude: 26.0963 and Longitude: 27.7752). During AMD collection, some parameters of AMD water were determined on site using a multiparameter meter (HANNA instruments, Johannesburg, RSA). These included $\mathrm{pH}$, total dissolved solids (TDS), and Electrical conductivity (EC). Initial concentration of metals (Al, $\mathrm{Cu}, \mathrm{Fe}, \mathrm{Mn}, \mathrm{Ni}$, and $\mathrm{Zn}$ ) in AMD was analyzed using inductively coupled plasma optical emission spectrometry (ICP-OES), 5110 ICP-OES vertical dual view, Agilent technologies Australia, made in Malaysia. The ICP-OES was coupled with Agilent SPS 4 Auto sampler, whereas the $\mathrm{SO}_{4}{ }^{2-}$ concentration was analyzed using an Ion chromatography (IC) (850 professional IC Metrohm, Herisau, Switzerland). All the parameters were analyzed following the "Standard Methods of the Examination of Water and Wastewater" [47].

Quality Assurance and Quality Control (QA/QC)

A QA/QC process was applied in this study to ensure the collection and production of trustworthy results. The QA/QC process embraced the collection and preservation of the samples. Analysis was done in triplicates, and data reported as mean values was considered 
acceptable when the difference within triplicate samples was less than $10 \%$. The value below detection limit (BDL) was in line with EPA guidelines for analyzing data [48], while the accuracy of the analysis was monitored using the National Institute of Standards and Technology (NIST) water standards. The water-Q4 database was utilized. The plant substrate was modeled using PH REdox EQuilibrium (in C language) (PHREEQC). The water potential precipitation of metals was determined using saturation indexes (SI), in which $\mathrm{SI} \leq 1$ denotes under-saturation, $\mathrm{SI} \approx 1$ denotes saturation, and $\mathrm{SI} \geq 1$ denotes super-saturation.

\subsection{Experimental Setup}

\subsubsection{Vertically Flowing Wetland Design and Description}

The pilot plants consisted of the following: (a) one reservoir tank to contain AMD and (b) another reservoir tank to contain fresh water for control. Two plastic basins with a capacity of $100 \mathrm{~L}$ were used, each measuring $100 \mathrm{~cm} \mathrm{~L} \times 60 \mathrm{~cm} \mathrm{~W} \times 50 \mathrm{~cm} \mathrm{H}$, for treatment and control (Figure 1). The new germinated seedlings of Vetiver, described in Section 2.1, were transplanted into the two basins containing soil as substrate to have two wetlands (one for experiment and one for control). The wetlands were continuous flow systems, where water was flowing continuously for the duration of the experiment. The wetlands were connected to the tank via a perforated conduit pipe and contained a total of 20 plants planted at equidistance to each other. A control valve was incorporated at the baseline of each tank to regulate the flow rate of water from tank to the wetland cell. The outlet structure of each wetland cell was an orifice with a valve to collect leachate for the analysis. Preventive maintenance measures, such as trash and debris removal and the elimination of mosquito breeding habitats, was applied in a routine basis to maintain the operation and safe function of the wetland, while corrective maintenance measures were applied in a non-routine basis, i.e., when needed.

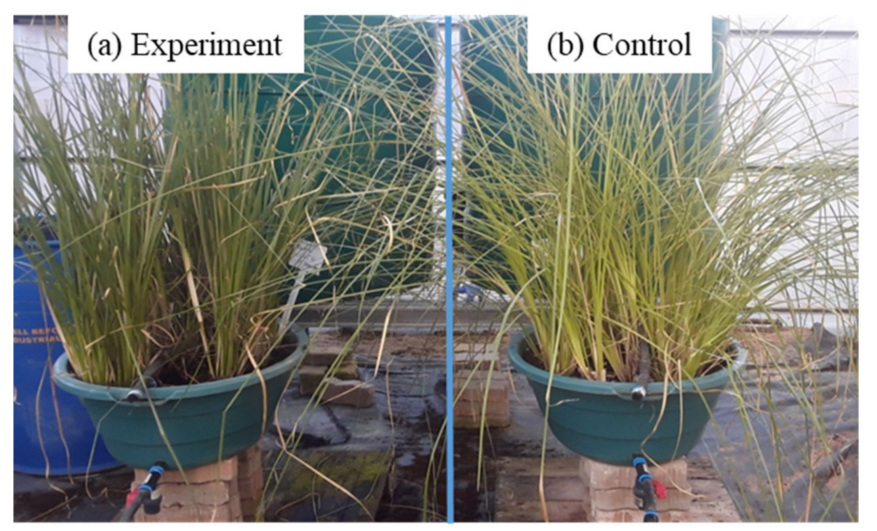

Figure 1. Experimental set-up of the SSVF-CW. (a) experiment and (b) control.

\subsubsection{Pre-Treatment of AMD Water and Chemical Composition of the Substrate}

Prior to the treatment, AMD water was filtered to remove total suspended solid (TSS) susceptible to clog the pipe, while the chemical composition of the substrate before and after contact with water (AMD) was done using X-ray fluorescence (XRF) and X-ray diffraction (XRD). The analyses were performed using a Thermo Fisher ARL-9400 XP+ Sequential XRF with winXRF Software. Mineralogical composition was ascertained using $X$-ray diffraction (XRD). The system was calibrated using a drip plastic bottle, and fed into the system as continuous drops. The average flow per unit time was calculated using the Darcy's law Equation (2):

$$
Q=\frac{\text { Qin }+ \text { Qout }}{2}=K A S
$$

where $Q$ is the average flow per unit time, $K$ is the hydraulic conductivity of a unit area in the medium perpendicular to the flow direction $\left(\mathrm{m}^{3} / \mathrm{d}\right), A$ is the total cross-section area 
perpendicular to the flow $\left(\mathrm{m}^{2}\right)$, and $S$ is the hydraulic gradient of the water surface in the flow system $(\mathrm{m} / \mathrm{m})$.

Once the average flow rate $(3 \mathrm{~L} /$ day) was calculated $(Q)$, the results were used to determine the hydraulic retention time (HRT), as illustrated in Equation (3) [49], taking into account the sizes of the wetland cell and the porosity of substrate:

$$
\mathrm{HRT}=\frac{V \times d}{Q}
$$

where $V$ is the volume of the wetland cell $\left(\mathrm{m}^{3}\right), d$ is the porosity of the wetland substrate $(\%)$, and $Q$ is the average flow through the wetland $\left(\mathrm{m}^{3} / \mathrm{d}\right)$ :

$$
\mathrm{HRT}=\frac{1 \times 0.6 \times 0.25 \times 0.6}{0.003}
$$

The maximum determined HRT was 30 days, and during that period, the inlet flow rate and outlet flow rate were monitored daily to ensure a steady flow of water in and out of the wetland. The flow rate was maintained low (3 L/Day) and the HRT (30 days) long in order to allow the water to spend more time in the wetland cells, thereby improving the performance of the wetland, since the studies of Conn and Fiedler [50], Ewemoje et al. [51], and Piñeyro et al. [52] revealed that the performance of the wetland is improved by high hydraulic retention time (HRT). At the end of the experiment (just after 30 days), the plants were harvested from both wetlands (treatment cell and control) for the assessment of the uptake and translocation of chemical species.

\subsubsection{Product Water and Soil Sampling}

Water samples (experiment and control) were collected daily from each wetland from the first day (Day 0) of HRT to the last day (Day 30) of HRT. An analysis was performed and the average result of five-day period was considered. Water samples were collected into amber glass bottles of $500 \mathrm{~mL}$. After collection, samples were divided into two sub-samples of $400 \mathrm{~mL}$ and $100 \mathrm{~mL}$. The sub-samples of $400 \mathrm{~mL}$ were used for the analysis in situ of $\mathrm{pH}$, TDS, and EC, while the sub-samples of $100 \mathrm{~mL}$ was used for the analysis of ex situ parameters, which included metals $(\mathrm{Al}, \mathrm{Cu}, \mathrm{Fe}, \mathrm{Mn}, \mathrm{Ni}, \mathrm{Zn})$ and $\mathrm{SO}_{4}{ }^{2-}$. Soil samples were air dried for one week followed by an analysis for metal concentration.

\subsubsection{Analytical Methods}

Product water from both wetlands (control and treatment cell) were analyzed in triplicate following standard methods. Electrical conductivity (EC), $\mathrm{pH}$, and TDS were determined using Hanna HI 83200 multi-parameter and the manufacturer's manual was followed with reference to standard methods for the examination of water and wastewater [47]. Prior to the analysis of the metal concentration, water samples were filtered through a $0.22-\mu \mathrm{m}$ pore syringe filter membrane to remove particles and preserved by adding two drops of nitric acid $\left(\mathrm{HNO}_{3}\right)$ concentrated to prevent ageing and immediate precipitation of metals. The filtrates were refrigerated at $4{ }^{\circ} \mathrm{C}$ prior to analysis by ICP-OES. $\mathrm{SO}_{4}{ }^{2-}$ was determined using IC. Soils samples were air dried for one week, sieved, and one gram $(1 \mathrm{~g})$ was digested in a mixture of $5 \mathrm{~mL}$ of $55 \%\left(\mathrm{HNO}_{3}\right)$ and $2 \mathrm{~mL} \mathrm{30 \%} \mathrm{Hydrogen}$ peroxide $\left(\mathrm{H}_{2} \mathrm{O}_{2}\right)$ using microwave digestion. Once digested, the samples were cooled to room temperature and the solutions were filtered through a $0.22-\mu \mathrm{m}$ pore syringe filter membrane and analyzed for metal concentrations by ICP-OES with a detection limit of $0.0001 \mathrm{mg} / \mathrm{L}$ and a margin of error of $10 \%$.

\subsection{Treatment Efficiency of Subsurface Vertical Flow Constructed Wetland (SSVF-CW)}

The efficiency of SSVF-CW in AMD water treatment was determined gradually during the duration of the experiment. The parameters of concern were analyzed daily and the removal efficiency (RE) was calculated after every five-day period for the duration of the experiment (30 days). The RE was determined using Equation (4) [53,54]: 


$$
R E=\frac{\mathrm{Ci}-\mathrm{Cf}}{\mathrm{Ci}} \times 100
$$

where $\mathrm{Ci}$ is the initial concentration of each parameter in the AMD water, $\mathrm{Cf}$ is the final concentration of each parameter after 30 days of retention time, and $R E$ is the removal efficiency of each parameter after 30 days of retention time (in percentage).

\subsection{Plant Harvesting}

Plants from each wetland (treatment cell and control cell) were harvested without damaging the roots and were rinsed separately with distilled water to remove dust, soil, and mineral particles. Plants were air dried at $25^{\circ} \mathrm{C}$ for one week and weighed to determine the tolerance index, as shown in Equation (5). The tolerance index (TI) according to Wilkins (1979) is the ratio between a variable measured in treated plants and that in control plants, and was calculated considering the dry plant weight. The tolerance index (TI) was calculated as the mean weight (biomass) of a dry plant grown in the AMD wetland divided by the mean weight of a dry plant grown in a control wetland [55]:

$$
\text { Tolerance index }(\mathrm{TI})=\frac{\text { biomass of plant growing in AMD cell }}{\text { Biomass of plants growing in potable fresh water cell }}
$$

\subsubsection{Digestion of Plants and Metal Analysis}

The plants' biomasses were separated into two samples (shoots and roots). Each part of the plant was dried and grinded using a mortar and pestle, and $1 \mathrm{~g}$ was digested with $10 \mathrm{~mL}$ of $65 \% \mathrm{HNO}_{3}$ (AR grade; $\mathrm{BDH}$ ). The digestate samples were then filtered using a $0.22-\mu \mathrm{m}$ pore syringe filter membrane followed by a metal content analysis using ICPOES. The concentration of metals in each portion of the plant allowed the researchers to determine the bio-concentration factor (BCF), translocation factor (TF), and the contribution of plant, substrate, and external factors in chemical species removal. The (BCF) of each metal was calculated, as illustrated in Equation (6), to determine the quantity of metals that moved from the wetland to the plant [56], while the TF indicates the ability of the plant to translocate metal from the roots to the aerial part of the plants [57]. The following equations were used:

$$
\begin{gathered}
\mathrm{BCF}=\frac{\text { Metal concentration in plant tissue }}{\text { Final concentration of metals in AMD water }} \\
\mathrm{TFx}=\frac{\text { metal concentration in shoots }}{\text { metal concentration in roots }}
\end{gathered}
$$

\subsubsection{Functional Group and Morphology of Vetiveria Zizanioides Roots}

Functional groups of grinded grass roots were determined using a PerkinElmer Spectrum 100 Fourier Transform Infrared Spectrometer (FTIR) equipped with a PerkinElmer Precisely Universal Attenuated Total Reflectance (ATR) sampling accessory equipped with a diamond crystal, while morphological properties and spot analysis of grass roots and was determined using SEM-EDS. Grinded roots samples were mounted on carbon tape that was attached to $\mathrm{Al}$ ends. Samples were viewed in a JEOL 5400 LV SEM with an attached KEVEX electron detector (JEOL, Tokyo, Japan). They were viewed in low vacuum mode and the metals were detected with a Sigma EDS spectrometer.

\subsection{Partitioning of Metals between Substrate, Plant, and External Factors}

Prior to the start of the experiment, the initial concentration of metals in substrate was determined. After 30 days of the experimental period, the quantity of metal retained in the wetland $\left(\mathrm{M}_{\mathrm{W}}\right)$ was determined using Equation (8):

$$
\mathrm{M}_{\mathrm{w}}=\mathrm{X}-\mathrm{Y}
$$


where $\mathrm{X}$ is the initial concentration of metal in AMD water, $\mathrm{Y}$ is the final concentration of metal in AMD water, and $\mathrm{M}_{\mathrm{W}}$ is the concentration of metal retained in the wetland.

The substrate's contribution $\left(\mathrm{M}_{\mathrm{s}}\right)$ to overall metal removal was also determined; it is the difference between the final metal concentration in the substrate and the initial metal concentration in the substrate Equation (9):

$$
\mathrm{M}=\mathrm{Z}-\mathrm{T}
$$

where $\mathrm{T}$ is the initial concentration of metal in the substrate and $\mathrm{Z}$ is the final concentration of metal in the substrate.

To estimate the contribution of external factors (ExF) in the overall metal removal, the metal concentration in the substrate $\left(\mathrm{M}_{\mathrm{S}}\right)$ was summed with the metal concentration in plants $\left(\mathrm{M}_{\mathrm{p}}\right)$, and the total was compared to wetland metal $\left(\left(\mathrm{M}_{\mathrm{w}}\right)\right.$ content, as per Equation (10):

$$
\operatorname{ExF}=\mathrm{M}_{\mathrm{w}}-\left(\mathrm{M}_{\mathrm{s}}-\mathrm{M}_{\mathrm{p}}\right)
$$

\section{Results and Discussion}

The results for this study will be categorized into the aqueous samples and solid samples. This will emphasize the findings which were acquired from different experiments and techniques.

\subsection{Characterization of Aqueous Samples}

\subsubsection{Effect of SSVF-CW on the Sulfate Concentration}

The effect of SSVF-CW on the removal of $\mathrm{SO}_{4}{ }^{2-}$ from AMD is reported in Figure 2.

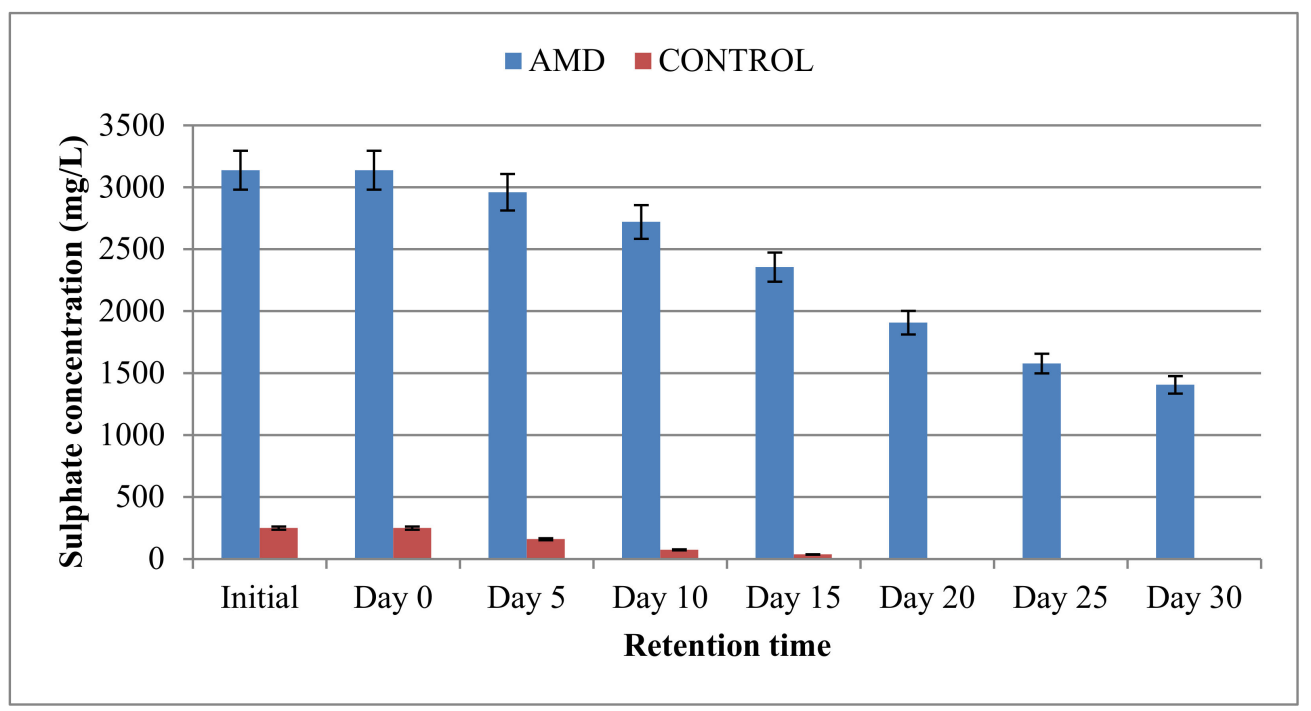

Figure 2. The effect of SSVF-CW on the removal of sulfate from AMD in 30 days HRT under a hydraulic loading rate of $3 \mathrm{~L} /$ day.

Figure 2 shows that the concentration of $\mathrm{SO}_{4}{ }^{2-}$ decreased from $3137 \mathrm{mg} / \mathrm{L}$ on the 1st day of retention time to $1406 \mathrm{mg} / \mathrm{L}$ on the 30th day, resulting in a removal efficiency of $55.18 \%$ (Figure 2). The results, therefore, revealed that SSVF-CW with Vetiveria zizanioides can remove $\mathrm{SO}_{4}{ }^{2-}$, and thereby, confirms other studies [58]. However, the removal percentage depends on the retention time and the initial concentration of $\mathrm{SO}_{4}{ }^{2-}$ in AMD. In the meantime, the concentration of sulfate in control wetland gradually decreased from day 1 to day 25 and remained constant until the end of experiment. The process of $\mathrm{SO}_{4}{ }^{2-}$ removal in SSVF-CW can be attributed to chemicals reaction occurring within the wetland. According to Chen et al. [59] and Balci et al. [60], the oxidation-reduction (redox) reaction occurring within the wetland can transform $\mathrm{SO}_{4}{ }^{2-}$ into elemental or mixed-valence-state form of sulfur, which facilitates its absorption by plants. Others compounds, such as 
thiosulfate and tetrathionate, have been detected in oxidized sulfide minerals and may have a crucial role in $\mathrm{SO}_{4}{ }^{2-}$ reduction in SSVF-CW [60]. The conversion of $\mathrm{SO}_{4}{ }^{2-}$ to sulfide $\left(\mathrm{S}^{2}\right)^{-}$can be seen as an initial step toward $\mathrm{SO}_{4}{ }^{2-}$ reduction in wetland due to the fact that $\mathrm{S}^{2-}$ can be precipitated in the presence of metals such as Mn and especially Fe from AMD water [59]. Dissimilatory Sulfate Reduction (DSR) and sulfide oxidation have been reported with constructed wetlands containing Phragmites australis and Juncus effusus, though DSR was the main removal mechanism [61]. The removal of $\mathrm{SO}_{4}{ }^{2-}$ can also be attributed to the DBR, since $\mathrm{SO}_{4}{ }^{2-}$ reduction generates $\mathrm{H}_{2} \mathrm{~S}$, which can form metals $\mathrm{S}^{2-}$ with divalent ions, such as $\mathrm{Fe}^{2+}$ or $\mathrm{Cu}^{2+}$ [62]. The reduction of $\mathrm{SO}_{4}{ }^{2-}$ may also be attributed to the increase of the $\mathrm{pH}$ value following the metal solubility reduction in AMD water and especially iron due to sedimentation. Plants' uptake, metals sedimentation, and DSR may, thus, be considered as possible mechanisms of $\mathrm{SO}_{4}{ }^{2-}$ removal.

\subsubsection{Effect of SSVF-CW on Heavy Metal Concentration}

The effect of SSVF-CW on the removal of metals from acid mine drainage (AMD) is reported in Figure 3a,b.
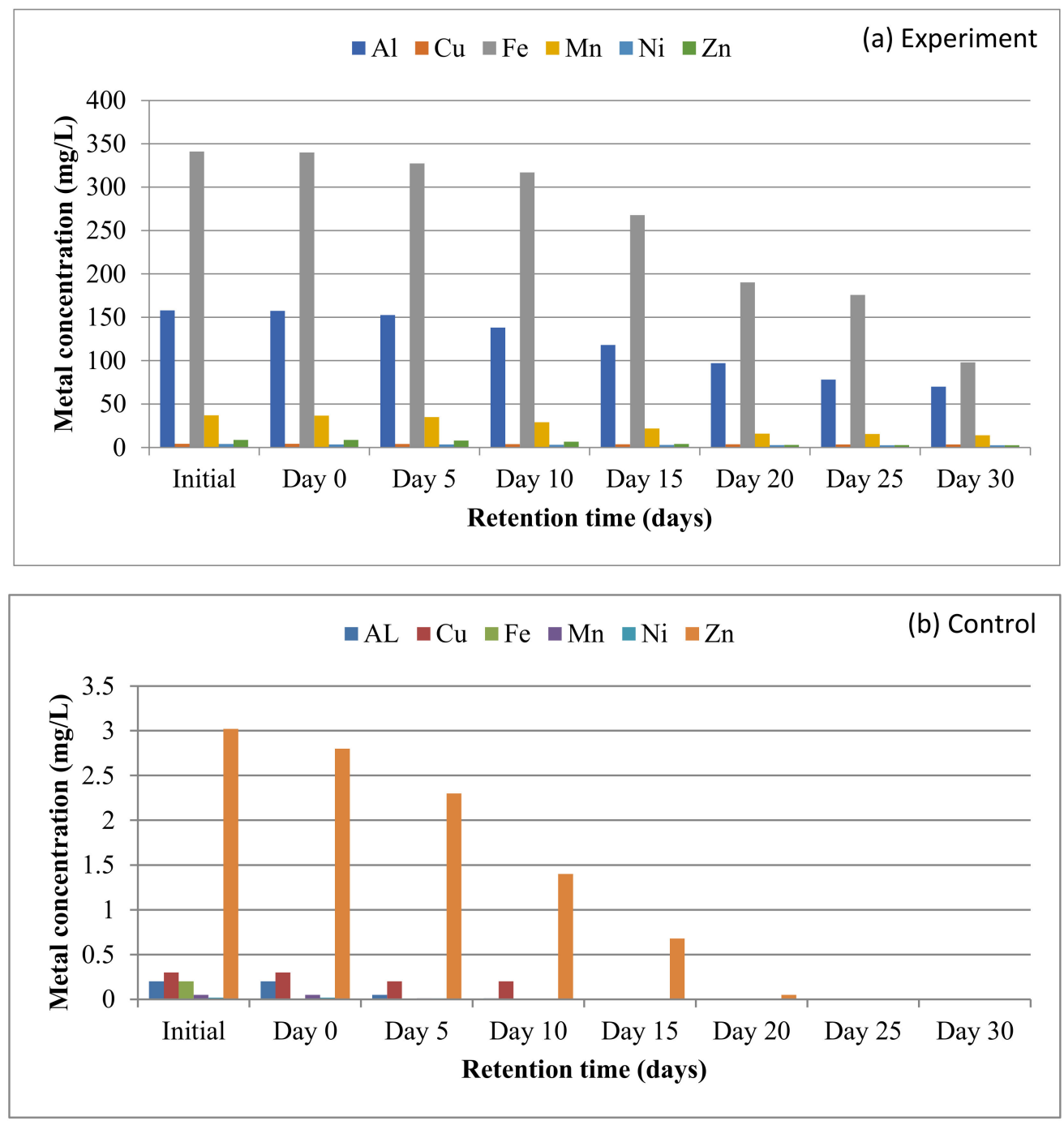

Figure 3. (a) Variation of the metal concentration in treatment wetland in 30 days of retention time under a hydraulic loading rate of $3 \mathrm{~L} /$ day. (b) Variation of metal concentration in control wetland in 30 days of retention time under a hydraulic loading rate of $3 \mathrm{~L} /$ day. 
Figure 3 a reveals that the metal concentration significantly decreased during the 30 days of retention time but with different removal efficiency for each metal. For instance, iron decreased slowly for the first 10 days and then drastically until the end of the experiment, whereas others metals decreased slowly from the beginning until the end (Figure 3a). The metal concentration reduction can be attributed to sedimentation and accumulation by Vetiveria zizanioides. In the meantime, the concentrations of metals in the control wetland decreased and were below the detection limit of $0.0001 \mathrm{mg} / \mathrm{L}$ at the end of the experiment for all metals (Figure 3b). This can be explained by the sedimentation and accumulation by Vetiveria zizanioides. In fact, a metal such as Fe plays a crucial role in plant metabolism processes such as DNA synthesis, respiration, and photosynthesis, and its deficiency in plants leads to common nutritional disorders [63]. Metals such as $\mathrm{Cu}, \mathrm{Fe}, \mathrm{Zn}$, and $\mathrm{Mn}$ act as important co-factors for many enzymes and are essential for both mitochondrial and chloroplast functions [64]. Furthermore, zinc is one of the eight essential micronutrients. It is needed by plants in small amounts, and is crucial to plant development as it plays an important role in a wide range of processes, such as growth hormone synthesis [65]. Many processes in plant metabolism, such as chloroplast formation, photosynthesis, nitrogen uptake, and synthesis of some enzymes, are directly linked to the presence of Mn in plant [66]. In addition, the sorption of metals in oxide form is widely known, as reported by Stumm and Morgan [67]. The oxide form plays an important role in metal removal in constructed wetland if $\mathrm{Fe} / \mathrm{Mn}$ oxides are present.

\subsubsection{Metal Concentration in Substrate}

The effect of SSVF-CW on the removal of metals from acid mine drainage (AMD) is reported in Figure $4 a, b$.

From Figure $4 \mathrm{a}$, it can be seen that the metal concentration in substrate increased gradually from day 1 up to day 15. Thereafter, the removal efficacy was observed to decrease until the end of the experiment. The increase in metal concentration during the first 15 days of retention time may be attributed to the continuous load of metals in the wetland, since it was a continuous flow system. After 15 days, the concentration of metals in the substrate decreased until the end of the experiment, and this may be attributed to plant accumulation of metals. In the control wetland (Figure $4 \mathrm{~b}$ ), the concentration of metals in the substrate remained almost constant for the first five days and then decreased to below the detection limit at the end of experiment; this may be attributed to the accumulation of metals by Vetiveria zizanioides (Figure $4 \mathrm{~b}$ ). The finding of this study showed that sedimentation plays an important role in metal removal by sequestering metals and facilitates their accumulation by plants. Sheoran and Sheoran [68] added that others processes, such as precipitation, must precedes sedimentation, since plants only accumulate precipitated metals. The use of compost soil as substrate in SSVF-CW seems to be recommended due to sorption capacity and ability to form new storage sediment without clogging the wetland. The reduction of pollutants in wetland is accomplished by diverse mechanisms, such as sedimentation, filtration chemical precipitation, adsorption, and microbial interactions in wetland media [69]. From the results above, it follows that substrate in wetland is one of the most important components in constructed wetland, since it provides a viable condition for maximum removal of pollutant. Metal removal in wetland varies depending on the type of plant species, the microbial diversity, and the physical and hydrodynamic characteristic, such as the depth and types of wetland [70] and temperature [71]. Elements have different affinities to different plant tissues once accumulated/complexed depending on their chemistry. This determines the easy or difficulty in the de-complexation from the plant tissues. Moreover, all elements are precipitated in the substrate, but their accumulation in plants depends on the pattern of metabolism of the plants. 

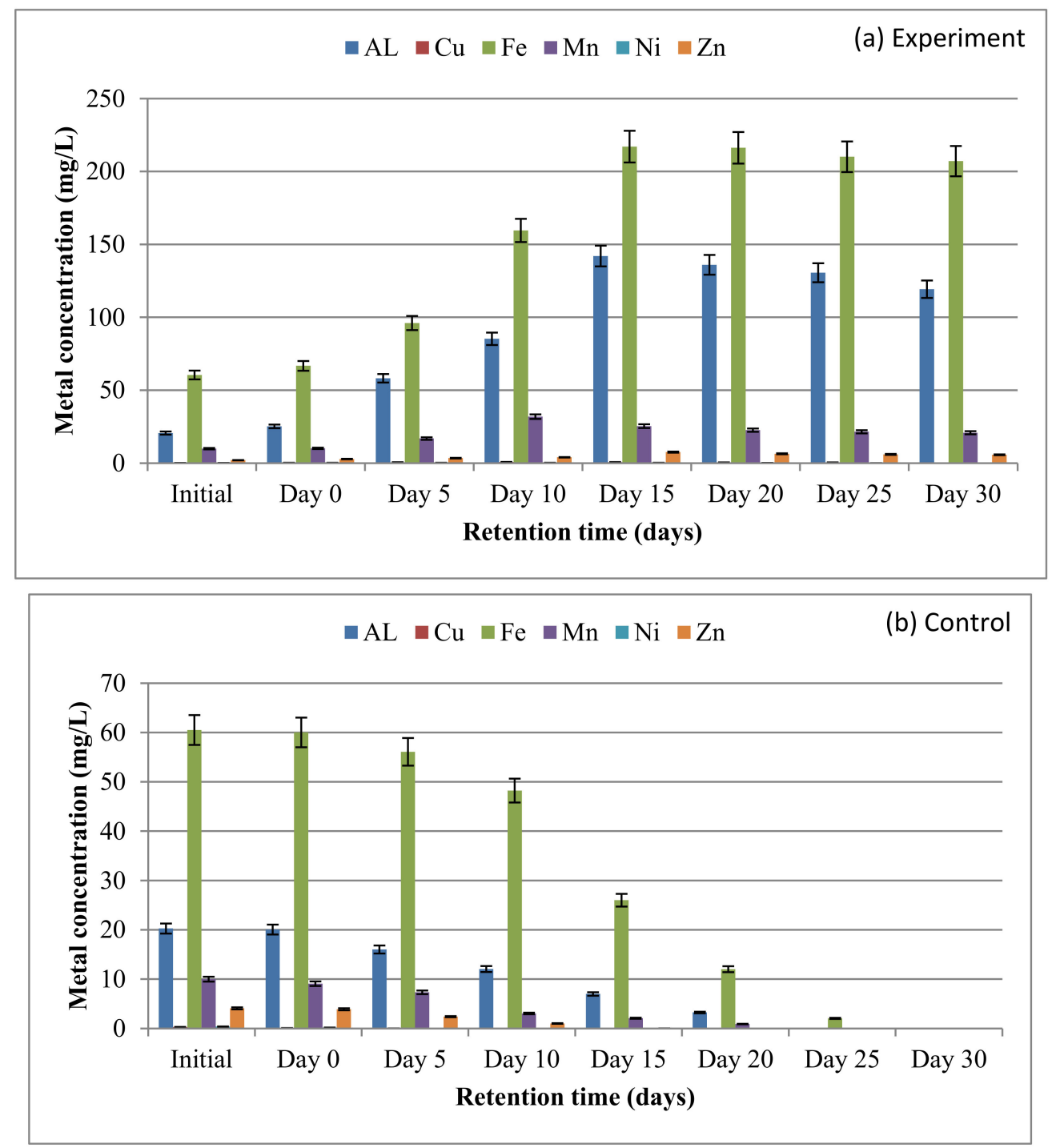

Figure 4. (a) Variation of the metal concentration in substrate (treatment wetland) within 30 days HRT and with a hydraulic loading rate of $3 \mathrm{~L} /$ day. (b) Variation of the metal concentration in substrate (control wetland) within 30 days HRT and with a hydraulic loading rate of $3 \mathrm{~L} /$ day.

\subsubsection{Removal Efficiency of Metals and Sulfate}

The removal efficiency of metals and sulfate by SSVF-CW is reported in Figure 5.

The removal efficiency is the percentage of a molecule of a given compound removed or destroyed during the treatment process (Figure 5). It was calculated gradually for each metal of concern and $\mathrm{SO}_{4}{ }^{2-}$ for the duration of experiments. The results showed that the metal removal percentage is ranked in the order: $\mathrm{Fe}(71.25 \%)>\mathrm{Zn}(70.40 \%)>\mathrm{Al}(68.93 \%)>$ $\mathrm{Mn}(62 \%)>\mathrm{SO}_{4}{ }^{2+}(55.18 \%)>\mathrm{Ni}(35 \%)>\mathrm{Cu}(18.83 \%)$. (Figure 5). These results were in line with the studies of Roongtanakiat et al. [72] for Fe and Mn, who used vertical subsurface constructed wetland. Two processes (Sedimentation and plants uptake) contribute to heavy metal removal in SSVF-CW [58]. Plants accumulate metals for their metabolism, and this may be the reason why metals such as iron are easily accumulated by Vetiveria zizanioides. Fe is the third most limiting nutrient for plant growth and metabolism, primarily due to the low solubility of the oxidized ferric form in aerobic environments [73]. In that regards, Fe deficiency results in common nutritional disorder in plants, leading to poor yields and reduced nutritional quality. The $\mathrm{SO}_{4}{ }^{2-}$ removal may also be attributed to the reduction of sulfur (S) in water, since $S$ is an important nutrient for optimal plant growth. It is one of the key macro elements essential for plant growth and it is taken up from the soil/water by 
the plant in sulfate form $\left(\mathrm{SO}_{4}{ }^{2+}\right)$. $\mathrm{S}$ is a component of methionine, cystine, and cysteine, which are three of the 21 amino acids that are the essential building block of proteins; see Brosnan and Brosnan [74] and Colovic et al. [75].

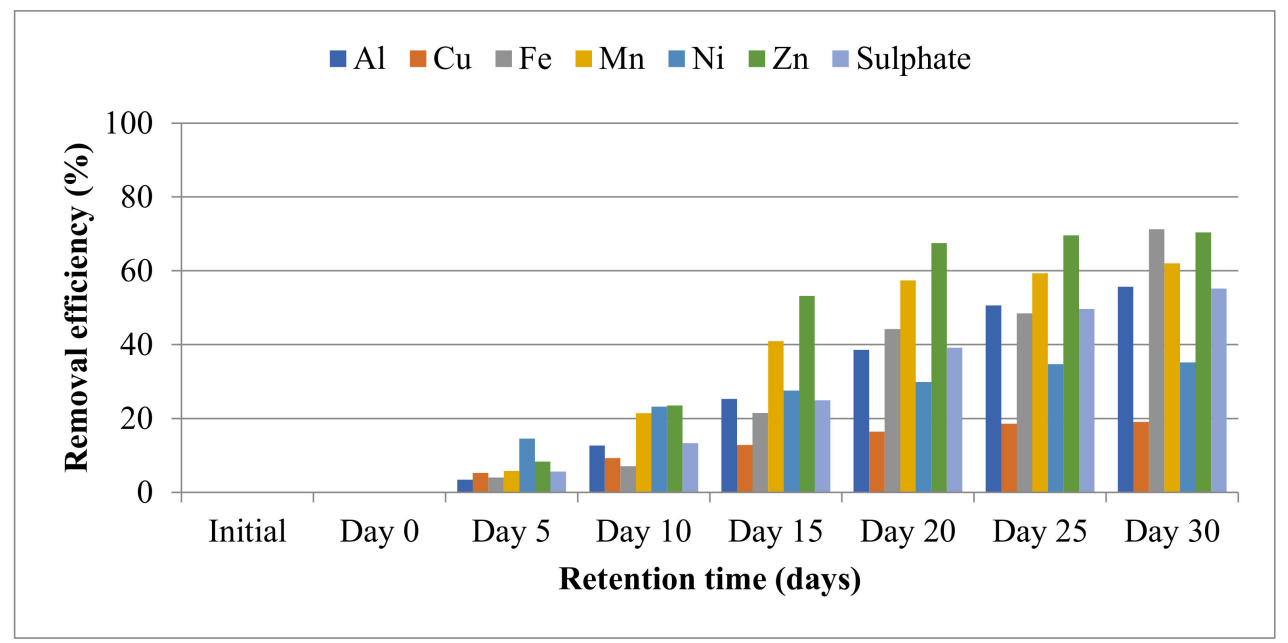

Figure 5. Removal efficiency of heavy metals and sulfate by SSVF in 30 days HRT under a hydraulic loading rate of $3 \mathrm{~L} /$ day.

\subsubsection{Tolerance Index}

For this experiment, the TI value was 1.03 (>1), which, according to Wilkins [76], reflects a net increase in plant biomass, revealing that Vetiveria zizanioides has developed tolerance. In both treatment and control wetland, all the plants were green and seemed healthy at the end of the experiment. The fact that Vetiveria zizanioides growing in AMD water remained green and seemed healthy after 30 days was not expected by the researchers, but this demonstrates that Vetiver is tolerant of a wide range of extreme conditions, such as very acidic medium $(\mathrm{pH}=2.7)$ or very alkaline conditions $(\mathrm{pH}=12)$ [77]. The Vetiveria zizanioides is a hydrophyte (wetland plant) due to its well-developed Sclerenchyma or air cell network [78], hence its high tolerance degree. Vetiver is also tolerant to high concentration of a wide range of heavy metals, whether individually or a combination of several heavy metals [77]. Following these characteristics, it can be concluded that Vetiveria zizanioides is an excellent candidate for a wide range of phytoremediations, as demonstrated in this study. The fact that Vetiver adapts itself to a very harsh conditions means Vetiver may have a specific cytogenetic composition allowing it to modify its metabolism according to the physic-chemical condition of the medium. However, this was not the objective of this project and may be the subject of further research.

\subsubsection{Bio-Concentration Factor (BCF)}

The bio-concentration factor $(\mathrm{BCF})$ demonstrates the potential success of the plant species for phytoremediation. A BCF greater than 1 is an indicator of how probable a metal can be bio accumulated by the plant species. It shows the heavy metal movement from soil to different plant parts, including their roots and shoots [57]. The BCF was calculated only for metals in the AMD-treated wetland, since the final concentration of all metals in control wetland was below the detection limit. The results are presented in Table 1.

Table 1. Bio-concentration factor of the metals of concern for Vetiveria zizanioides.

\begin{tabular}{ccccccc}
\hline Metals & Al & Cu & Fe & Mn & Ni & Zn \\
\hline BCF & 0.25 & 0.81 & 0.75 & 0.42 & 0.58 & 0.24 \\
\hline
\end{tabular}

As shown in Table 1 , the BCF of metals obeyed the following order: $\mathrm{Cu}(0.81)>\mathrm{Fe}$ $(0.75)>\mathrm{Ni}(0.58)>\mathrm{Mn}(0.42)>\mathrm{Al}(0.25)>\mathrm{Zn}(0.24)$. The dissimilitude of $\mathrm{BCF}$ results may be 
attributed to the variation in the heavy metal concentration in the medium and the ability of plants (Vetiveria zizanioides) to accumulate a specific metal. These results demonstrate that the concentration of heavy metals in plants is related to their availability in the wetland and their importance in plant metabolism. The results showed that Vetiveria zizanioides has not accumulated sufficient quantity of metals to be considered as hyper accumulator, since the BCF of metals was less than 1 . This can be attributed to the versatile ability of Vetiveria zizanioides to adapt under various harsh environmental conditions, and the ability to resist a complexity of heavy metal toxicities [79]. Furthermore, low intermediate accumulation may be explained by the flow pattern of the designed system. Although the current results show that Vetiveria zizanioides is not a hyper accumulator, but due to its high biomass content and tolerance index (TI), which is higher than 1, and its ability to accumulate various metals simultaneously further shows its high capability for phytoremediation in relation to others plants such as Pistia stratiotes and Eleocharis dulcis, which selectively accumulate only $\mathrm{Mn}$ and Fe, respectively [46,73].

\subsubsection{Metal Distribution and Translocation}

The translocation factors of metals grown in treatment and control wetland is shown in Table 2.

Table 2. Translocation factor (root/shoot) of AMD and control grown vetiver.

\begin{tabular}{ccccccc}
\hline TF & Al & Cu & Fe & Mn & Ni & Zn \\
\hline AMD & 0.05 & 0.85 & 0.44 & 2.06 & 0.75 & 0.53 \\
CONTROL & 0.03 & 0.83 & 0.27 & 0.12 & 1.85 & 0.41 \\
\hline
\end{tabular}

After 30 days of the experiment, Vetiveria zizanioides accumulated $\mathrm{Al}(95 \%), \mathrm{Fe}(69 \%)$, and $\mathrm{Zn}(65 \%)$ in the roots (Figure $6 \mathrm{a}$ ), with a TF of $0.05,0.44$, and 0.53 , respectively (Table 2). Figure 6a shows that the majority of $\mathrm{Cu}(54 \%)$ and $\mathrm{Ni}(57 \%)$ were accumulated in the roots with a TF of 0.85 and 0.75 , respectively, whereas there was great translocation of $\mathrm{Mn}$ $(67 \%)$ with a TF of 2.06 (Table 2). However, in the control wetland, Vetiveria zizanioides had greater $\mathrm{Mn}(89 \%)$ and Fe contents (79\%) in the roots (Figure 6b), with a TF of 0.12 and 0.27 , respectively, while the majority of $\mathrm{Al}(64 \%), \mathrm{Cu}(54 \%)$, and $\mathrm{Zn} \mathrm{(59 \% )} \mathrm{were} \mathrm{accumulated}$ in the roots with a TF of $0.03,0.83$, and 0.41 , respectively. A minority of $\mathrm{Ni}(35 \%)$ was accumulated in the roots with a TF of 1.85. The roots that grew in AMD-treated wetland showed amorphous and irregularly spaced build up along their surface from plaques, thereby reducing the translocation of metals from roots to shoots [80] (Figure 6a), which is not the case for roots that grew in control wetland (Figure 6b).

The difference between the TF of Mn in AMD water and control water may be attributed to the $\mathrm{pH}$ of the medium. The bioavailability of $\mathrm{Mn}$ in soil is, therefore, influenced by both $\mathrm{pH}$ and redox conditions [77]. Within a harsh environment such as AMD wastewater with various metals, including $\mathrm{Mn}$ and $\mathrm{Fe}$, Mn oxides form co-precipitates with $\mathrm{Fe}$, leading to the acidity of the medium with an increased redox potential of Mn oxides, which can be easily reduced in the soil exchange sites [81], thereby increasing the concentration of soluble $\mathrm{Mn}^{2+}$ [82], which is the predominant form of $\mathrm{Mn}$ in the soil solution and the most available $\mathrm{Mn}$ form for plants [83]. In contrast, when the $\mathrm{pH}$ is basic, chemical $\mathrm{Mn}^{2+}$ auto-oxidation is favored over $\mathrm{MnO}_{2}, \mathrm{Mn}_{2} \mathrm{O}_{3}, \mathrm{Mn}_{3} \mathrm{O}_{4}$, and even $\mathrm{Mn}_{2} \mathrm{O}_{7}$, which are not normally available to plants [82]. In addition, alkaline $\mathrm{pH}$ promotes the chemisorption of Mn into soil particles, decreasing their availability [84]. Moderate translocation of $\mathrm{Ni}$ in vetiver grown in both AMD and control wetlands can be attributed to the biochemical processes of sequestration and translocation, since $\mathrm{Ni}$ can be transported as a nickel-histidine complex [85]. These two biochemical processes ensure high mobility of Ni within the plant, which can justify the moderate translocation of Nickel [86]. The moderate translocation of $\mathrm{Cu}$ by vetiver grown in both wetlands may be attributed to plaque inhibition, thereby requiring more time to accumulate copper [87]. 

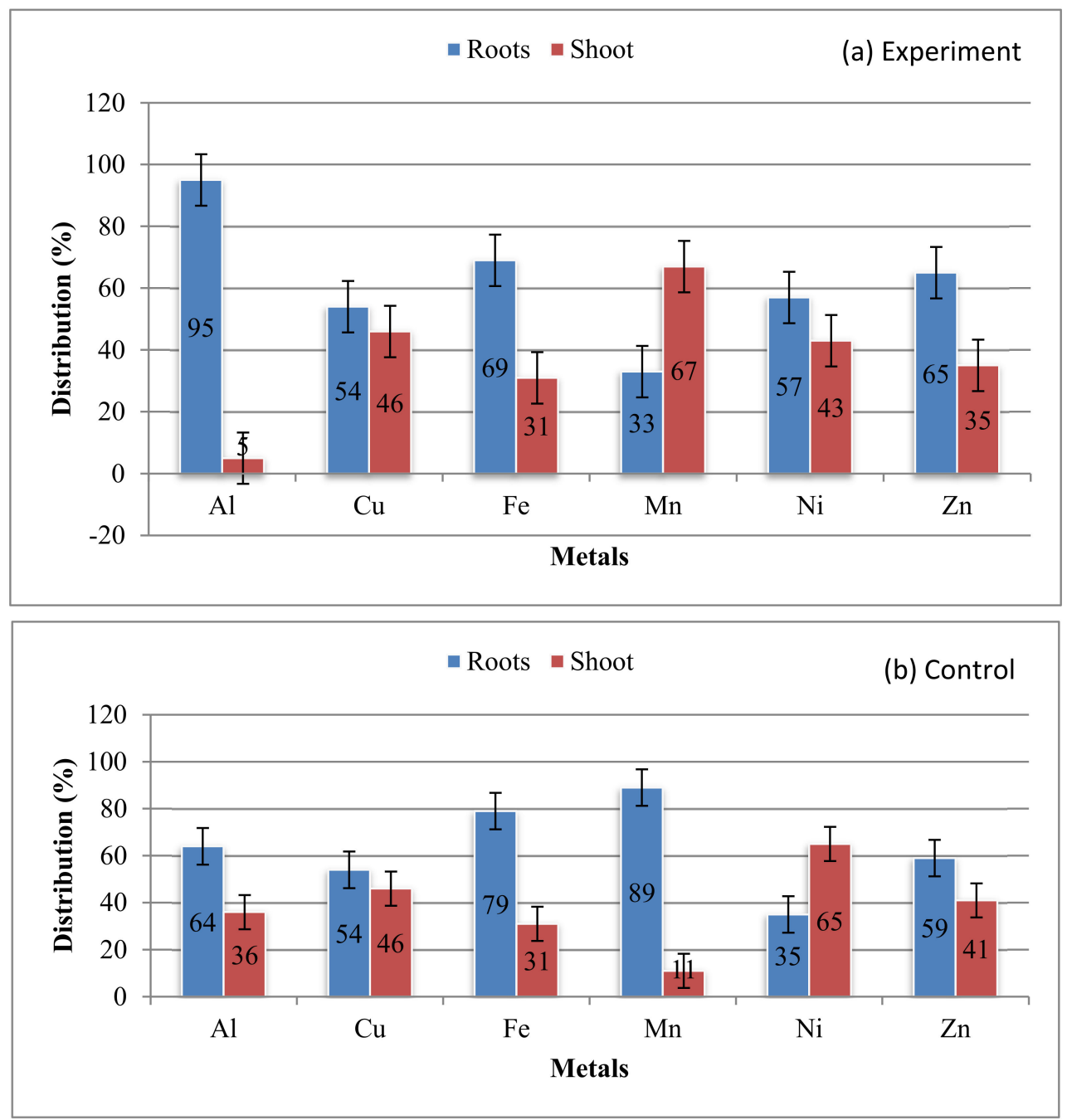

Figure 6. (a) Percentages of the metal distribution partitioned into roots and shoots (treatment wetland). (b) Percentages of the metal distribution partitioned into roots and shoots (control wetland).

The low translocation of $\mathrm{Al}$ may be attributed to plant tolerance strategy, since in an acidic condition, $\mathrm{Al}$ becomes a major constraint for the growth of plant. At a $\mathrm{pH}$ value less than 6, $\mathrm{Al}^{2+}$ is oxidized to $\mathrm{Al}^{3+}$ following Equation (11):

$$
\mathrm{Al}^{2+}+\mathrm{e}^{+} \rightarrow \mathrm{Al}^{3+}
$$

The $\mathrm{Al}^{3+}$ released to the medium enters into the root tip cell and delays the growth of the plant [88]. There was a greater translocation of Fe by Vetiver grown from both wetlands: $69 \%$ and $79 \%$ for AMD and control, respectively. The higher translocation of $\mathrm{Mn}$ and $\mathrm{Zn}$ in both wetlands may be attributed to the need of the aforementioned metals for plant metabolism, since $\mathrm{Mn}$ and $\mathrm{Zn}$ are essential nutrients [87]. A number of factors, including types of metals, plant species, types of substrate, and the initial concentration of metals, anatomical, biochemical, and physiological factors influence the metals' translocation from roots to shoots [89]. In fact, metals are taken up from the soil by roots and transported via the plasma membrane driven by ATP-depended proton pumps that catalyze $\mathrm{H}^{+}$extrusion across the membrane. Furthermore, along with cationic nutrients, plant transporters are also involved in shuttling potentially toxic cations across plant membranes [85]. Cytogenetic make-up and others unknown factors can be attributed to different patterns of metal translocations from roots to shoots [90]. 


\subsubsection{Metal Removal Partitioned between Substrate, Plant, and External Factors}

The contribution of substrate, Vetiver, and external factors in the removal efficiency of metals was determined and the results are shown in Figure 7.

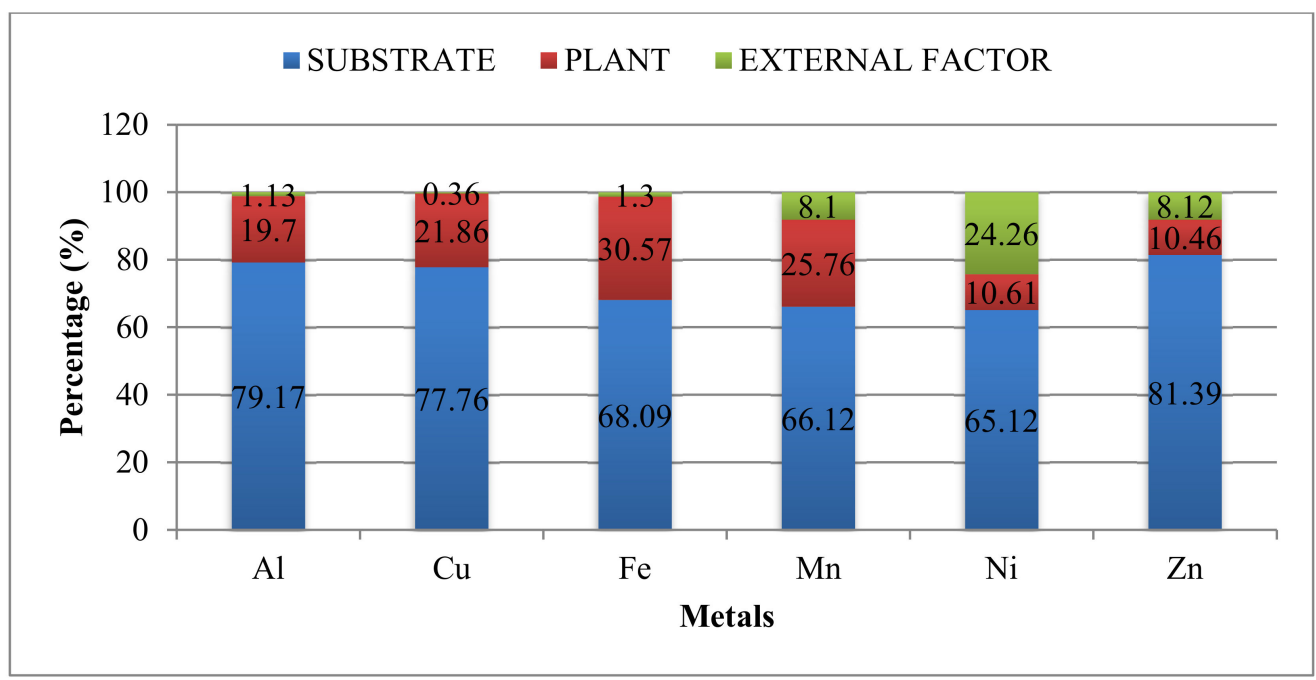

Figure 7. Removal efficiency of metals partitioned between Vetiver, substrate, and external factors.

The determination of the final concentration of metals in AMD water, substrate, and in plant tissue allowed the researchers to calculate the contribution of each wetland component (substrate and plant) and external factor in overall metal removal process. The results revealed that metals were more removed by the wetland substrate, followed by vetiver and external factors, with substrate contributing to $81.39 \%, 79.17 \%, 77.76 \%, 68.09 \%$, $66.12 \%$, and $65.12 \%$ removal of $\mathrm{Zn}, \mathrm{Al}, \mathrm{Cu}, \mathrm{Fe}, \mathrm{Mn}$, and $\mathrm{Ni}$, respectively (Figure 7). The substrate provides support to plant growth, serves as an energy source for biogeochemical reactions, and also plays a major role in pollutant reduction, since it absorbs pollutants such as heavy metals, thereby facilitating their accumulation by the plants roots [91].

Plant contribution in the overall metal removal process was ranged in the order: $\mathrm{Fe}(30.57 \%)>\mathrm{Mn}(25.76 \%)>\mathrm{Cu}(21.86 \%)>\mathrm{Al}(19.70 \%)>\mathrm{Ni}(10.61 \%)>\mathrm{Zn}(10.46 \%)$ (Figure 7) The contribution of vetiver to the metal removal was small compared to the substrate fraction in the overall metal removal, and this may be attributed to the duration of experiment (30 days) and the need of metals for plant metabolism. For instance, $\mathrm{Cu}$ and $\mathrm{Zn}$ are essential elements for plant metabolism; however, at elevated concentrations, they become toxic [92]. Therefore, more time may be required for the plant (VZ) to accumulate considerable quantities of metals. Despite its smaller contribution in overall metal removal in SSVF-CW, Vetiver, similar to other plants used in constructed AMDtreatment wetlands, contributed to the overall efficiency of $\mathrm{CW}$ in many ways. It favored the settlement of total suspended solid (TSS) and provides optimum conditions for the growth of microorganisms, thereby promoting the sedimentation and accumulation of metals in CW [93]. The contribution of external factors was ranged in the order: $\mathrm{Ni}$ $(24.26 \%)>\mathrm{Zn}(8.12 \%)>\mathrm{Mn}(8.10 \%)>\mathrm{Fe}(1.3 \%)>\mathrm{Al}(1.13)>\mathrm{Cu}(0.36 \%)$ (Figure 7$)$. They include: evaporation, adsorption, biological assimilation, decomposition, chemical transformation, and volatilization; sulfides and others minerals in the sediment may also contribute significantly to metal removal in CW [94]. The finding was in line with the study by Mustapha et al. [46], who used SSVF-CW with three different plants (Typha. latifolia; Cyperus alternifolius; Cynodon dactylon) for heavy metal removal from refinery wastewater and found that metal accumulation by plants and externals factors accounted only for a small fraction of the overall metal removal in subsurface vertical flow wetland. 


\subsection{Characterization of the Solid Samples}

\subsubsection{X-ray Fluorescence (XRF) Analysis}

An XRF analysis was done to determine the elemental composition of initial soil, soil from control wetland, and soil from treatment wetland, and the results are shown in Table 3.

Table 3. The elemental composition of initial soil, soil from control wetland, and soil from treatment wetland.

\begin{tabular}{cccc}
\hline Samples (wt.\%) & Initial Soil & Control Soil & AMD Reacted Soil \\
\hline $\mathrm{Fe}$ & 84.9504 & 84.9532 & 88.8688 \\
$\mathrm{Ti}$ & 4.6093 & 2.6774 & 4.3403 \\
$\mathrm{Rb}$ & 3.2519 & 3.8190 & 2.3403 \\
$\mathrm{Sr}$ & 2.7486 & 3.7355 & 2.7808 \\
$\mathrm{Mn}$ & 2.3030 & 2.6018 & 3.4293 \\
$\mathrm{Zn}$ & 0.6970 & 0.7001 & 0.4873 \\
$\mathrm{Si}$ & 0.1393 & -0.3210 & 0.0291 \\
$\mathrm{Al}$ & - & 0.0393 \\
$\mathrm{Na}$ & $\mathbb{0 . 4 5 0 5}$ & 0.0007 & 0.0324 \\
$\mathrm{Ni}$ & & & 0.0291 \\
\hline
\end{tabular}

From the results in Table 3, it follows that the percentage of Fe and Mn was the same for the initial and control soil. However, the percentage of Fe and Mn were found to increase after reaction of soil with AMD, and this may be attributed to the addition of metals content and formation of new phases. This corroborates results reported in the water quality assays. The percentage of $\mathrm{Zn}, \mathrm{Ni}$, and $\mathrm{Si}$ decreased after contact of substrate (soil) with AMD water, indicating the possible dissolution of these metals. $\mathrm{Al}$ and $\mathrm{Na}$ were found to be present, and this may have originated from AMD water. The results also revealed that there was no noticeable difference in the elemental composition between initial soil and soil from control wetland, which may be attributed to the potable fresh water used in control wetland, which in fact does contain an insignificant quantity of chemicals.

\subsubsection{X-ray Diffraction (XRD) Analysis}

An XRD analysis was done to determine the mineralogical composition of initial soil, soil from treatment wetland, and soil from control wetland, and the results are shown in Figure 8 . In addition, Table 4 lists the mineral phases identified with their various peaks.

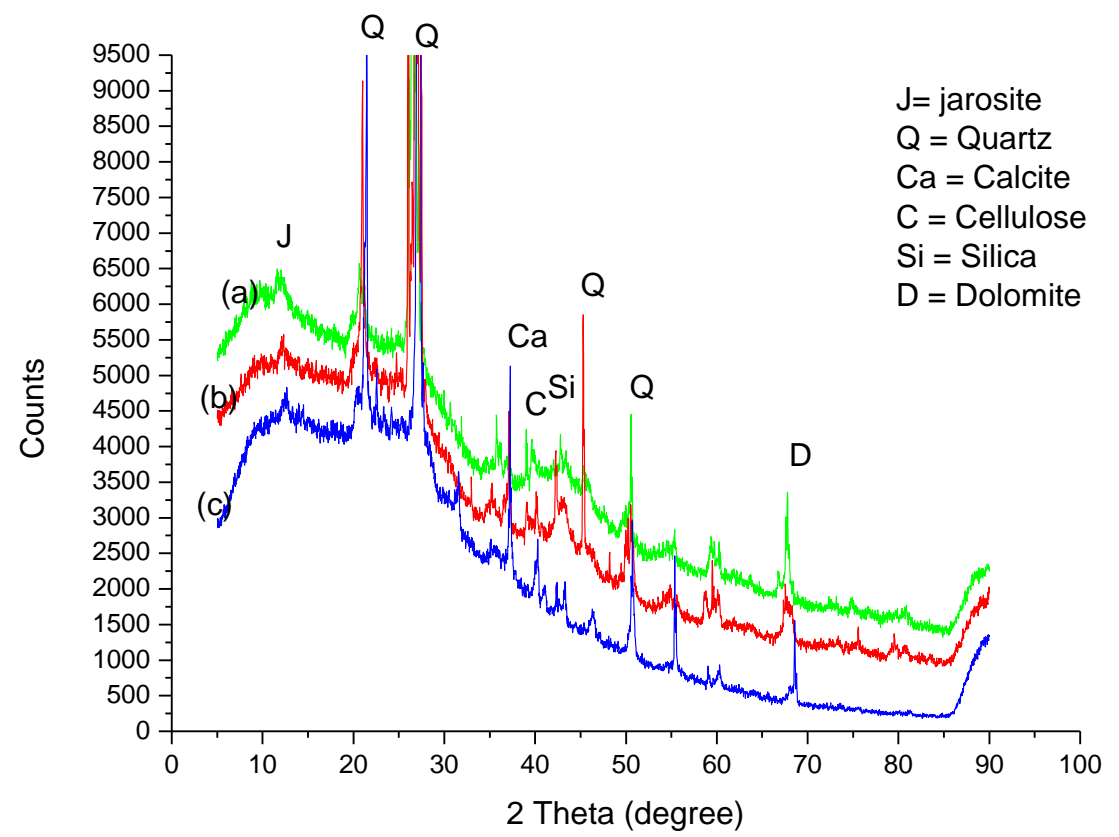

Figure 8. (A-C) XRD patterns of substrate: treatment (A), control (B), and initial substrate (C). 
Table 4. The measured XRD and the identified mineral phase of the initial substrate, substrate from experimental wetland, and substrate from control wetland.

\begin{tabular}{cccc}
\hline Substrate & 2 Theta (Degree) & Mineral Phase & References \\
\hline Initial soil & Quartz & 21 & {$[96]$} \\
& Quartz & 28 & {$[96]$} \\
& Calcite & 37.5 & {$[97]$} \\
& Cellulose & 40.1 & \\
& Silica & 46 & {$[96]$} \\
& Quartz & 50 & {$[96]$} \\
Quil from control wetland & Quartz & 55 & {$[95]$} \\
& Dolomite & 68 & \\
& Quartz & 21 & {$[98]$} \\
& Quartz & 27 & {$[96]$} \\
& Calcite & 37 & {$[96]$} \\
& Cellulose & 38 & {$[99]$} \\
& Silica & 44 & {$[98]$} \\
& Quartz & 45 & {$[96]$} \\
& Quartz & 50 & {$[96]$} \\
& Dolomite & 67 & {$[99]$} \\
& Jarosite & 8 & {$[96]$} \\
& Quartz & 21 & {$[98]$} \\
& Quartz & 26 & {$[96]$} \\
& Calcite & 35 & {$[99]$} \\
\hline
\end{tabular}

As shown in Figure 8, the X-ray diffraction patterns of substrate from experimental wetland (a) and control wetland (b) and initial substrate showed several peaks spread over the range $2 \theta$ from $10^{\circ}$ to $68^{\circ}$, although at different intensities. The peaks at $2 \theta=20.6^{\circ}, 28^{\circ}$, $45^{\circ}$, and $50^{\circ}$ may correspond to Quartz $\left(\mathrm{SiO}_{4}\right)$, which is the major elemental component of compost [95]. Jarosite is present in a substrate from the experimental wetland with peak at 8, and this may be a ferric iron-sulfate mineral with the formula $\left(\mathrm{K}, \mathrm{H}_{3} \mathrm{O}\right) \mathrm{Fe}_{3}\left(\mathrm{SO}_{4}\right)_{2}(\mathrm{OH})_{6}$ that originated from AMD water with acidic $\mathrm{pH}$.

\subsubsection{Fourier Transforms Infrared Spectroscopy Analysis}

Fourier transforms infrared spectroscopy (FTIR) analysis of roots grown from both wetlands (treatment and control) was done and the results are presented in Figure 9 while Table 5 lists the identified metals' functional groups and their respective wavelengths.

Table 5. The metals' functional groups and their references.

\begin{tabular}{ccc}
\hline Wavenumber & Functional Group & Reference \\
\hline 698 & $\mathrm{Fe}-\mathrm{O}$ & {$[6]$} \\
780 & $\mathrm{Si}-\mathrm{O}$ & {$[99]$} \\
1080 & $\mathrm{SO}_{4}$ & {$[12]$} \\
1559 & $\mathrm{C}=\mathrm{O}$ & {$[100]$} \\
2222 & $\mathrm{O}-\mathrm{H}$ & {$[101]$} \\
2996.5 & $\mathrm{O}-\mathrm{H}$ & {$[99]$} \\
\hline
\end{tabular}




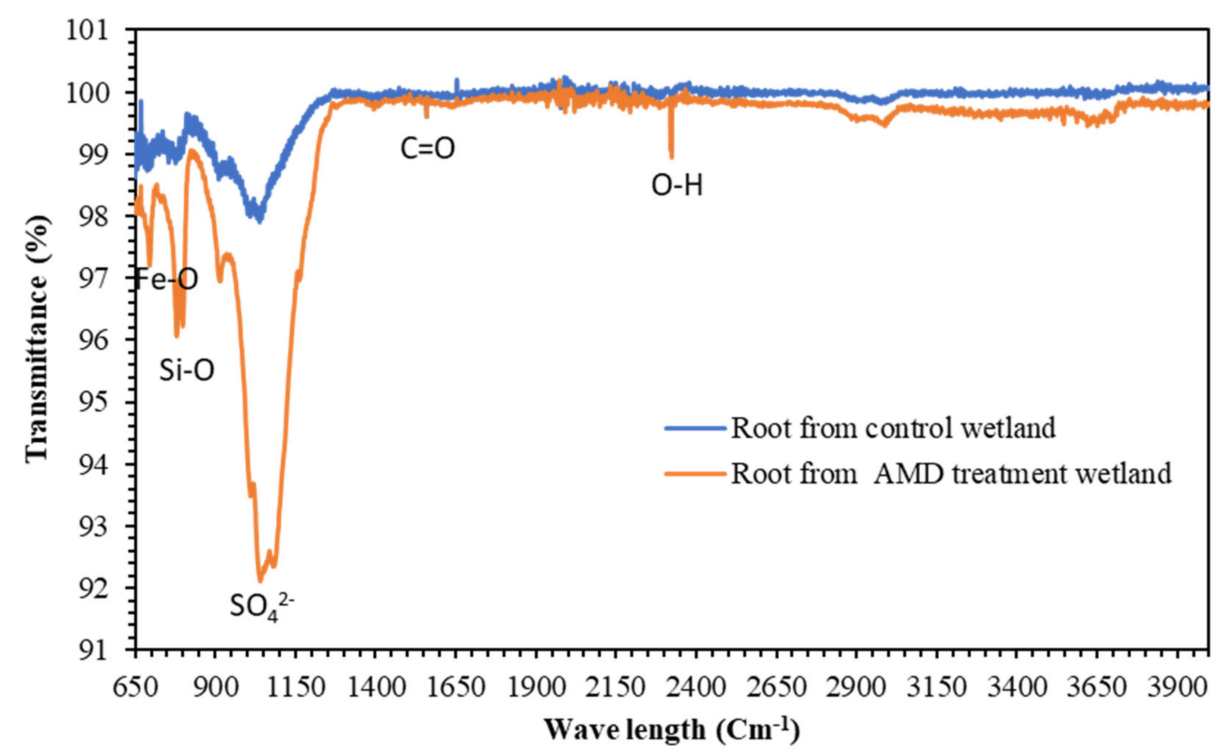

Figure 9. Fourier Transfer Infrared (FTIR) spectra of root from AMD treatment wetland and root from control wetland.

FTIR spectra of Vetiveria zizanioides grown in AMD-treated wetland and control wetland in Figure 9 indicates the complex formations between the pollutants in AMD water and different part of Vetiveria zizanioides cell wall. The bands in the roots grown in control wetland are characteristic of vibration, corresponding to the band at $3498 \mathrm{~cm}^{-1}$. The stretching vibration of the roots from control wetland correspond to the bands at 3032, 2814.5, $1998.5,1489.5$, and $1274 \mathrm{~cm}^{-1}$, while in the roots from AMD-treated wetland, the stretching vibration corresponds to the bands at $3495,2937,2323.5$, and $1345.5 \mathrm{~cm}^{-1}$. The doublet at 1026 and 1105 for roots from AMD wetland and the doublet at 857 and 966.5 for roots from control wetland may be attributed to the formation of carbonate $\left(\mathrm{CaCO}_{3}\right)[102]$ from calcium present in roots from both wetlands, as revealed by the EDS results (Figure 10a,b). Furthermore, sulfates $\left(900-1200 \mathrm{~cm}^{-1}\right)$ [14] and iron oxides $\left(450-500 \mathrm{~cm}^{-1}\right)$ were also present [6].
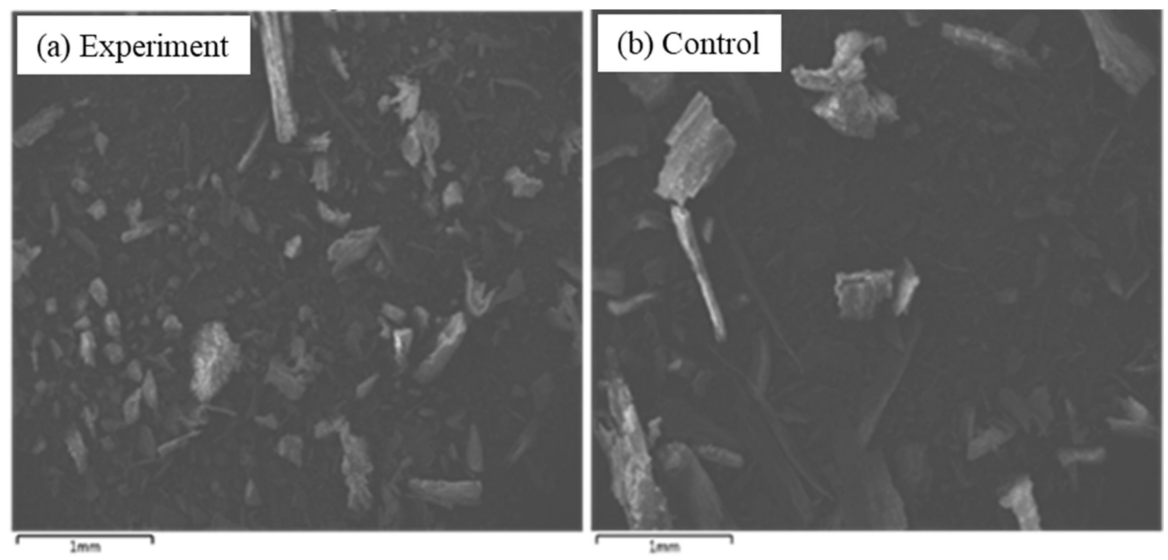

Figure 10. (a,b). SEM of Vetiveria zizanioides roots from AMD-treated wetland water (a) and control wetland $(\mathbf{b})$.

\subsubsection{Scanning Electron Microscope Electron Dispersion Spectrometry Analysis}

To understand the mode of interaction of AMD with Vetiveria zizanioides and the formation of mineral phases, a scanning electron microscope (SEM) was used to assess the change in morphology of Vetiveria zizanioides roots reacted with AMD water (Figure 10a) and Vetiveria zizanioides root reacted with potable fresh water (Figure 10a). The SEM images of roots grown in AMD water (Figure 10a) and the SEM images of Vetiveria zizanioides roots 
grown in potable fresh water (Figure 10b) showed a noticeable difference in morphology. This result concurs with the findings obtained by Kiiskila et al. [103]. In fact, plants use their cell wall as a defense compartment to respond to toxic conditions and accumulate pollutants. Pollutants are accumulated by plants using the cell wall, which is rich in proteins, amino acids, and phenolics able to bind pollutants in order to render them less or non-toxic. When plants accumulate metals using the cell wall, it leads to the formation of crystal-like deposits, which saturates the cell wall, creating cell thickening. This demonstrates that Vetiveria zizanioides has accumulated and sequestrated toxic pollutants, as illustrated by Figure 10a. The SEM image of Vetiveria zizanioides roots from control wetland showed less thickening compared to the SEM image of roots from AMD wetland, thereby demonstrating that $\mathrm{VZ}$ growth in control wetland accumulated fewer pollutants.

The EDS results of vetiver roots grown in AMD water revealed the presence of $\mathrm{C}$, $\mathrm{O}, \mathrm{Mg}, \mathrm{Au}, \mathrm{Si}$, and $\mathrm{Fe}$. The presence of $\mathrm{Ca}$ indicates the presence of Calcite. The reacted Vetiveria zizanioides with $\mathrm{AMD}$ contained $\mathrm{O}, \mathrm{Al}, \mathrm{K}$, and $\mathrm{Si}$ as the major components. The presence of oxygen at high levels may be the results of precipitation of AMD elements to metal oxides. High levels of $\mathrm{Fe}$ and $\mathrm{Al}$ are possibly due to the phenomena of ion exchange on the soil surface (substrate) and precipitation following the slight increase of $\mathrm{pH}$. The ion exchange process leads to the release of some metals [22] and the presence of Potassium $(\mathrm{K})$, Calcium (Ca), and Magnesium (Mg) in root growth in the AMD environment may be the result of an ion exchange reaction, whereas the presence of $S$ compounds could be attributed to the sink of heavy metals released into the environment (Figure 11a). The EDS of roots from control wetland revealed the presence of the same components in addition to $\mathrm{Na}$ but with a very low percentage, thereby confirming the $\mathrm{X}$-ray fluorescence analysis results (Figure 11b). The components of roots from control wetland may be attributed to their presence in substrate used as wetland media.
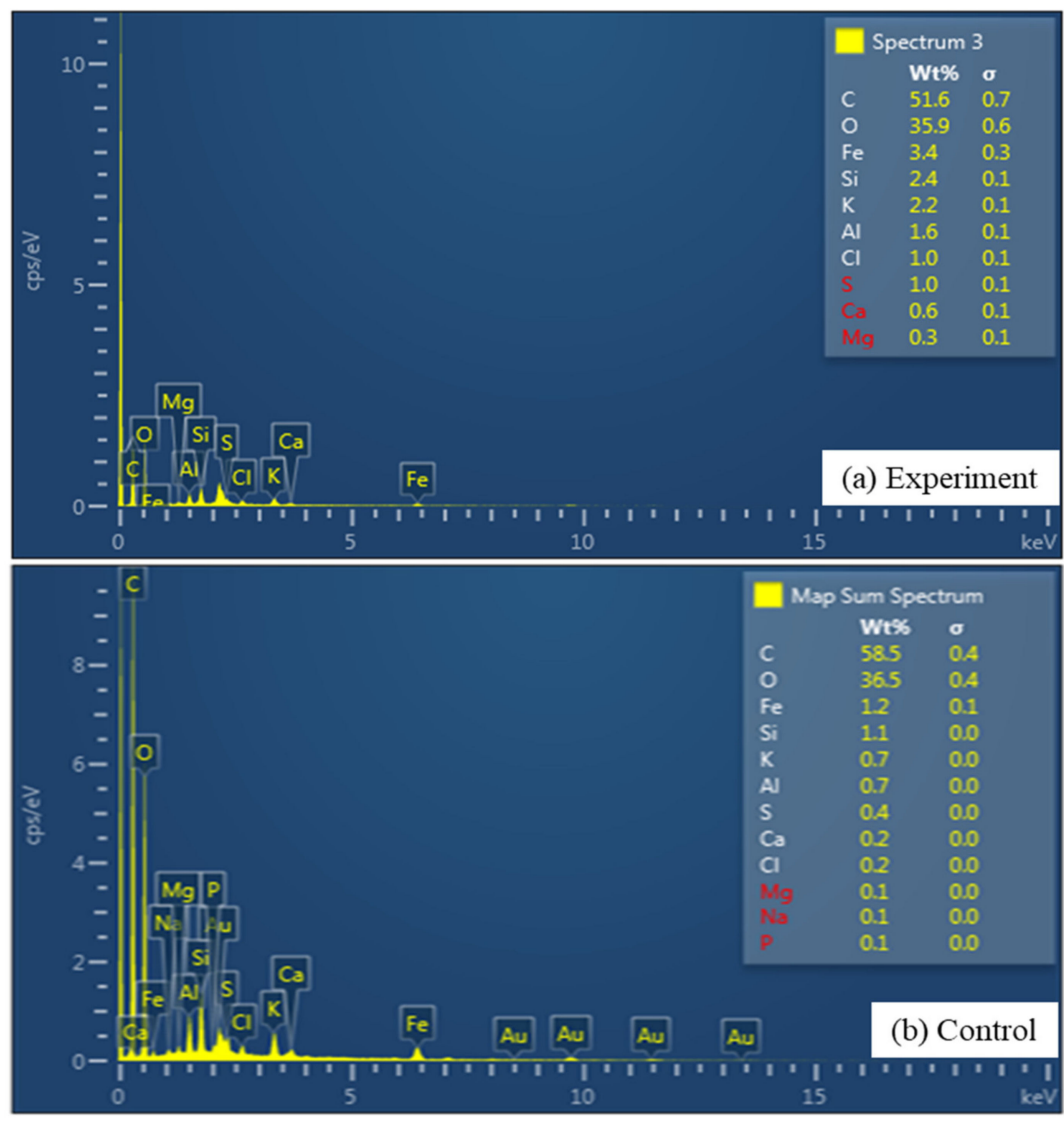

Figure 11. (a,b) EDS of Vetiveria zizanioides roots from AMD-treated (a) and control wetland (b). 


\section{Chemical Species for Untreated and AMD-Treated Wetland with SSVF-CW}

The results of chemical species of AMD were used to compare the guidelines standards for effluent from the department of environmental affairs (DEA) and DWAS, and the results are presented in Table 6.

Table 6. Concentrations of chemical species for untreated and AMD-treated wetland with SSVF-CW (all units in mg/L except $\mathrm{pH}$ and $\mathrm{EC})$.

\begin{tabular}{ccccc}
\hline Parameters & Raw AMD & $\begin{array}{c}\text { DEA/DWAS Guidelines for } \\
\text { Effluent Discharge }\end{array}$ & AMD-Treated Water & $\begin{array}{c}\text { Percentage of } \\
\text { Pollutant Removed }\end{array}$ \\
\hline pH & 2.6 & $6-12$ & 3.8 & - \\
TDS & 3380 & $2400 \mathrm{mg} / \mathrm{L}$ & 1400 & 58.57 \\
$\mathrm{EC}$ & 5000 & $150 \mu \mathrm{S} / \mathrm{cm}$ & 3200 & 36.00 \\
$\mathrm{Al}$ & 158 & $20 \mathrm{mg} / \mathrm{L}$ & 98.03 & 56.68 \\
$\mathrm{Fe}$ & 341 & $50 \mathrm{mg} / \mathrm{L}$ & 14.06 & 71.24 \\
$\mathrm{Mn}$ & 37 & $20 \mathrm{mg} / \mathrm{L}$ & 3.40 & 62 \\
$\mathrm{Cu}$ & 4.2 & $20 \mathrm{mg} / \mathrm{L}$ & 2.53 & 70.04 \\
$\mathrm{Zn}$ & 8.55 & $20 \mathrm{mg} / \mathrm{L}$ & 2.54 & 35 \\
$\mathrm{Ni}$ & 3.92 & $10 \mathrm{mg} / \mathrm{l}$ & 1406 & 55.18 \\
Sulfate & 3137 & $2400 \mathrm{mg} / \mathrm{L}$ & \\
\hline
\end{tabular}

The $\mathrm{pH}$ is very acidic (2.6), with high TDS and EC. Higher TDS and EC may be attributed to high levels of $\mathrm{Al}, \mathrm{Fe}$, and $\mathrm{Mn}$, other macro-elements, such as $\mathrm{Na}, \mathrm{Ca}$, and $\mathrm{Mg}$, and microelements, such as $\mathrm{Cu}, \mathrm{Zn}, \mathrm{Pb}, \mathrm{Co}, \mathrm{Ni}, \mathrm{B}, \mathrm{Cr}, \mathrm{Mo}$, Se, As, K, and Si, and a high concentration of sulfate. After treatment of AMD with SSVF-CW using Vetiveria zizanioides, the $\mathrm{pH}$ increased slightly from 2.6 to 3.01, whereas EC and TDS decreased. The concentrations of metals $\left(\mathrm{Al}, \mathrm{Cu}, \mathrm{Fe}, \mathrm{Mn}, \mathrm{Ni}\right.$, and $\mathrm{Zn}$ ) and $\mathrm{SO}_{4}{ }^{2-}$ decreased significantly after treatment with SSVF-CW, and this can be attributed to sedimentation/precipitation and accumulation by Vetiveria zizanioides. However, the DWAS water quality guidelines have not been met, and therefore, there is a need to associate or integrate subsurface vertical flow constructed wetland with another type of passive treatment, such as free water constructed wetland, or with active technology, such as neutralization or filtration, in order to improve the AMD water quality.

\section{Conclusions}

Vetiveria zizanioides was successfully explored for the removal of contaminants from acid mine drainage (AMD). Findings from this study further revealed that Vetiveria zizanioides has high tolerance to AMD, and this has been confirmed by a zero to trivial sign of toxicity response after 30 days of hydraulic retention and hydro-dynamics. Interestingly, (i) a lower removal efficiency for $\mathrm{Ni}$ and $\mathrm{Cu}$ were observed, with (ii) moderate removal of $\mathrm{SO}_{4}{ }^{2}$ reported, while (iii) higher removal efficiency was observed for $\mathrm{Fe}, \mathrm{Zn}, \mathrm{Al}$, and $\mathrm{Mn}$. The finding further revealed that the attenuation of metals could be explained by the partitioning of extracted chemical species between wetland substrate, plant, and external factors with a substrate contribution of approximately $65.12 \%$ to $81.39 \%$ with $\leq 31 \%$ of $\mathrm{Al}, \mathrm{Cu}, \mathrm{Fe}, \mathrm{Mn}, \mathrm{Ni}$, and $\mathrm{Zn}$ stored in the plant. The removal efficacy of chemical species was observed to obey the following order: Fe $(71.25 \%)>\mathrm{Zn}(70.40 \%)>\mathrm{Mn}(62 \%)>\mathrm{Al}$ $(56.68 \%)>\mathrm{SO}_{4}{ }^{2-}(55.18 \%)>\mathrm{Ni}(35 \%)>\mathrm{Cu}(18.83 \%)$. Furthermore, metals were more concentrated in the roots, except $\mathrm{Mn}$, which was more concentrated in the shoot. The PH REdox EQuilibrium (in C language) (PHREEQC) geochemical model confirmed that metals existed as di- and-trivalent complexes in the solution. Lastly, the available metals were precipitated as metal hydroxides and oxy-hydrosulfates. A significant quantity of pollutants of concern was removed from AMD water, but we did not reach the guideline standards for effluent discharge as established by the DEA/DWAS and World Health Organization (WHO). As such, we recommend the coupling with a secondary AMD treatment technology to ensure that the treated water is of an acceptable standard. 
Author Contributions: Conceptualization, B.N., V.M., T.A.M.M., and M.T.; Formal analysis, B.N.; Methodology, B.N., V.M., T.A.M.M., and M.T.; Data curation, B.N., V.M., and T.A.M.M.; writing—original draft, B.N.; Supervision, V.M. and T.A.M.M.; writing-review and auditing, B.N., V.M., T.A.M.M., and M.T. All authors have read and agreed to the published version of the manuscript.

Funding: The research received no external funding.

Institutional Review Board Statement: The study was conducted according to the guidelines of the Declaration of Helsinki and approved by the Research Ethics Committee of the University of South Africa, Ethics Number: 2018/CAES/069.

Informed Consent Statement: Verbal agreement was obtained from mine where AMD water was collected.

Data Availability Statement: Not applicable.

Acknowledgments: The authors acknowledge the management of the Sibanye Gold mine in Krugersdorp for giving the opportunity to collect acid mine drainage water. The authors also thank the lab technician, Kagiso (put surname) of the Instutite of Nanotechnology and Water Sustainability (iNanoWS). The assistance and involvement of Sole from the department of chemistry and Ernest Berg during the project is acknowledged.

Conflicts of Interest: The authors declare that this research project has no conflict of interest.

\section{References}

1. Simate, G.S.; Ndlovu, S. Acid mine drainage: Challenges and opportunities. J. Environ. Chem. Eng. 2014, 2, 1785-1803. [CrossRef]

2. Kefeni, K.K.; Msagati, T.A.M.; Mamba, B.B. Acid mine drainage: Prevention, treatment options and resource recovery: A review. J. Clean. Prod. 2017, 151, 475-493. [CrossRef]

3. Rambabu, K.; Banat, F.; Pham, Q.M.; Ho, S.H.; Ren, N.Q.; Show, P.L. Biological remediation of acid mine drainage: Review of past trends and current outlook. Environ. Sci. Ecotechnol. 2020, 2, 100024. [CrossRef]

4. Masindi, V.; Akinwekomi, V.; Maree, J.P.; Muedi, K.L. Comparison of mine water neutralisation efficiencies of different alkaline generating agents. J. Environ. Chem. Eng. 2017, 5, 3903-3913. [CrossRef]

5. Masindi, V.; Ndiritu, J.G.; Maree, J.P. Fractional and step-wise recovery of chemical species from acid mine drainage using calcined cryptocrystalline magnesite nano-sheets: An experimental and geochemical modelling approach. J. Environ. Chem. Eng. 2018, 6, 1634-1650. [CrossRef]

6. Tabelin, C.B.; Ryosuke, S.; Igarashi, T.; Ilhwan, P.; Shuichi, T.; Takahiko, A.; Mayumi, I.; Naoki, H. Simultaneous leaching of arsenite, arsenate, selenite and selenate, and their migration in tunnel-excavated sedimentary rocks: I. Column experiments under intermittent and unsaturated flow. Sci. Total Environ. 2017, 186, 126-135. [CrossRef]

7. Tabelin, C.B.; Veerawattananun, S.; Ito, M.; Hiroyoshi, N.; Igarashi, T. Pyrite oxidation in the presence of hematite and alumina: II. Effects on the cathodic and anodic half-cell reactions. Sci. Total Environ. 2017, 581-582, 126-135. [CrossRef]

8. Masindi, V.; Osman, M.S.; Shingwenyana, R. Valorization of acid mine drainage (AMD): A simplified approach to reclaim drinking water and synthesize valuable minerals-Pilot study. J. Environ. Chem. Eng. 2019, 7, 103082. [CrossRef]

9. Baker, B.J.; Banfield, J.F. Microbial communities in acid mine drainage. FEMS Microbiol. Ecol. 2003, 44, 139-152. [CrossRef]

10. Sheoran, A.S.; Sheoran, V.; Choudhary, R.P. Bioremediation of acid-rock drainage by sulphate-reducing prokaryotes: A review. Miner. Eng. 2010, 23, 1073-1100. [CrossRef]

11. Amos, R.T.; Blowes, D.W.; Bailey, B.L.; Sego, D.C.; Smith, L.; Ritchie, A.I.M. Waste-rock hydrogeology and geochemistry. Appl. Geochem. 2015, 57, 140-156. [CrossRef]

12. Tabelin, C.B.; Igarashi, T.; Villacorte-Tabelin, M.; Ilhwan, P.; Einstine, M.; Opiso, M.; Naoki, H. Arsenic, selenium, boron, lead, cadmium, copper, and zinc in naturally contaminated rocks: A review of their sources, modes of enrichment, mechanisms of release, and mitigation strategies. Sci. Total Environ. 2018, 645, 1522-1553. [CrossRef]

13. Ilhwan, P.; Tabelin, C.B.; Sanghee, J.; Xinlong, L.; Kensuke, S.; Mayumi, I.; Naoki, H. A review of recent strategies for acid mine drainage prevention and mine tailings recycling. Chemosphere 2019, 219, 588-606. [CrossRef]

14. Tabelin, C.B.; Ryan, D.C.; Igarashi, T.; Villacorte-Tabelin, M.; Richard, D.A.; Kyoungkeun, Y.; Simit, R.; Mayumi, I.; Naoki, $\mathrm{H}$. Acid mine drainage formation and arsenic mobility under strongly acidic conditions: Importance of soluble phases, iron oxyhydroxides/oxides and nature of oxidation layer on pyrite. J. Hazard. Mater. 2020, 399, 122844. [CrossRef] [PubMed]

15. Akinwekomi, V.; Maree, J.P.; Zvinowanda, C.; Masindi, V. Synthesis of magnetite from iron-rich mine water using sodium carbonate. J. Environ. Chem. Eng. 2017, 5, 2699-2707. [CrossRef]

16. Naidu, G.; Ryu, S.; Thiruvenkatachari, R.; Choi, Y.; Jeong, S.; Vigneswaran, S. A critical review on remediation, reuse, and resource recovery from acid mine drainage. Environ. Pollut. 2019, 1110-1124. [CrossRef] [PubMed]

17. Masindi, V.; Foteinis, S.; Ndiritu, J.; Tekere, M. A review on prevention, treatment, beneficiation, and valorization of acid mine drainage: Advances and avenues towards circular economy. 2021; unpublished work. 
18. Department of Water Affairs. South African Water Quality Guidelines, 1st ed.; Department of Water Affairs: Pretoria, South Africa, 1996; Volume 8.

19. US EPA, United States-Environmental Protection Agency. Water Quality Standards Handbook: Chapter 3: Water Quality Criteria; EPA-823-B-17-001; United States-Environmental Protection Agency: Washington, DC, USA, 2017; pp. 1-26. Available online: www.epa.gov/sites/production/files/2014-10/documents/handbook-chapter3.pdf (accessed on 15 March 2020).

20. Nleya, Y.; Simate, G.S.; Ndlovu, S. Sustainability assessment of the recovery and utilisation of acid from acid mine drainage. J. Clean. Prod. 2015, 113, 17-27. [CrossRef]

21. Muhammad, S.N.; Kusin, F.M.; Zahar, M.S.M.; Halimoon, N.; Yusuf, F.M. Passive treatment of acid mine drainage using mixed substrate: Bacth experiment. Procedia Environ. Sci. 2015, 30, 157-161. [CrossRef]

22. Zewail, T.M.; Yousef, N.S. Kinetic study of heavy metal ions removal by ion exchange in batch conical air spouted bed. Alexandria Eng. J. 2015, 54, 83-90. [CrossRef]

23. Motsi, T.; Rowson, N.A.; Simmons, M.J.H. Adsorption of heavy metals from acid mine drainage by natural zeolite. Int. J. Miner. Process. 2009, 92, 42-48. [CrossRef]

24. Aguiar, A.; Andrade, L.; Grossi, L.; Pires, P. Amaral Acid mine drainage treatment by nanofiltration: A study of membrane fouling, chemical cleaning, and membrane ageing. Sep. Purif. Technol. 2017, 192, 185-195. [CrossRef]

25. Agboola, O. The role of membrane technology in acid mine water treatment: A review. Korean J. Chem. Eng. 2019, 36, 1389-1400. [CrossRef]

26. Igarashi, T.; Pepe, S.H.; Hiroyuki, U.; Hiroko, M.; Nobuyoshi, I.; Koichi, H.; Tabelin, C.B. The two-step neutralization ferriteformation process for sustainable acid mine drainage treatment: Removal of copper, zinc and arsenic, and the influence of coexisting ions on ferritization. Sci. Total Environ. 2020, 715, 136877. [CrossRef]

27. Lewis, A.E.; Nathoo, J.; Thomsen, K.; Kramer, H.J.; Witkamp, G.J.; Reddy, S.T.; Randall, D.R. Design of a Eutectic Freeze Crystallization process for multicomponent waste water stream. Chem. Eng. Res. Des. 2010, 88, 1290-1296. [CrossRef]

28. Sheoran, A.S. Management of Acidic Mine Waste Water by Constructed Wetland Treatment Systems: A Bench Scale Study. Eur. J. Sustain. Dev. 2017, 245-255. [CrossRef]

29. Herniwanti, H.; Priatmadi, J.B.; Yanuwiadi, B. Water Plants Characteristic for Phytoremediation of Acid Mine Drainage Passive Treatment. J. Basic Appl. Sci. 2013, 13, 1-14.

30. Herniwanti, H.; Yanuwiadi, B.; Priatmadi, J.; Soemarno. Comparison of Characteristic Aquatic Local Plants for Phytoremediation. J. Appl. Environ. 2014, 4, 167-176.

31. Kiiskila, J.D.; Sarkar, D.; Feuerstein, K.A.; Datta, R. A preliminary study to design a floating treatment wetland for remediating acid mine drainage-impacted water using vetiver grass (Chrysopogon zizanioides). Environ. Sci. Pollut. Res. 2017, 24, 27985-27993. [CrossRef] [PubMed]

32. Thongpitak, J.; Pekkoh, J.; Pumas, C. Remediation of Manganese-Contaminated Coal-Mine Water Using Bio-Sorption and Bio-Oxidation by the Microalga Pediastrum duplex (AARLG060): A Laboratory-Scale Feasibility Study. Front. Microbiol. 2019, 10, 1-14. [CrossRef]

33. Elghali, A.; Benzaazoua, M.; Bussière, B.; Genty, T. In situ effectiveness of Alkaline and cementitious amendments to stabilize Oxidized acid-generating tailings. Minerals 2019, 9, 314. [CrossRef]

34. Lounate, K.; Coudert, L.; Genty, T.; Mercier, G.; Blais, J.F. Performance of a Semi-passive Sulfate-reducing Bioreactor for Acid Mine Drainage Treatment and Prediction of Environmental Behavior of Post-treatment Residues. Mine Water Environ. 2020, 39, 769-784. [CrossRef]

35. Skousen, J.; Ziemkiewicz, P. Performance of 116 passive treatment systems for acid mine drainage. In Proceedings of the 22nd American Society of Mining and Reclamation Annual National Conference, Breckenridge, CO, USA, 19-23 June 2005; Volume 2, pp. 1100-1133.

36. Simmons, J.; Ziemkiewicz, P.; Black, D.C. Use of Steel Slag Leach Beds for the Treatment of Acid Mine Drainage: The McCarty Highwall Project. J. Am. Soc. Min. Reclam. 2002, 2002, 527-538. [CrossRef]

37. Esmaeili, A.; Mobini, M.; Eslami, H. Removal of heavy metals from acid mine drainage by native natural clay minerals, batch and continuous studies. Appl. Water Sci. 2019, 9, 1-6. [CrossRef]

38. RoyChowdhury, A.; Sarkar, D.; Datta, R. A combined chemical and phytoremediation method for reclamation of acid mine drainage-impacted soils. Environ. Sci. Pollut. Res. 2019, 14414-14425. [CrossRef]

39. Suman, J.; Uhlik, O.; Viktorova, J.; Macek, T. Phytoextraction of heavy metals: A promising tool for clean-up of polluted environment? Front. Plant Sci. 2018, 871, 1-15. [CrossRef]

40. Hawrot-Paw, M.; Patryk, R.; Małgorzata, M.; Jacek, S.; Adam, K.; Piotr, P.; Wojciech, G. Pea cultivar Blauwschokker for the phytostimulation of biodiesel degradation in agricultural soil. Environ. Sci. Pollut. Res. 2019, 26, 34594-34602. [CrossRef] [PubMed]

41. Zazouli, M.A.; Mahdavi, Y.; Bazrafshan, E.; Balarak, D. Phytodegradation potential of bisphenolA from aqueous solution by Azolla Filiculoides. J. Environ. Heal. Sci. Eng. 2014, 12, 1-5. [CrossRef]

42. Zgorelec, Z.; Bilandzija, N.; Knez, K.; Galic, M.; Zuzul, S. Cadmium and Mercury phytostabilization from soil using Miscanthus $\times$ giganteus. Sci. Rep. 2020, 10, 1-10. [CrossRef]

43. Roongtanakiat, N.; Tangruangkiat, S.; Meesat, R. Utilization of vetiver grass (Vetiveria zizanioides) for removal of heavy metals from industrial wastewaters. Sci. Asia 2007, 33, 397-403. [CrossRef] 
44. Perdana, M.C.; Sutanto, H.B.; Prihatmo, G. Vertical Subsurface Flow (VSSF) constructed wetland for domestic wastewater treatment. IOP Conf. Ser. Earth Environ. Sci. 2018, 148, 1-10. [CrossRef]

45. Marín-Rivera, J.V.; Martínez-Girón, J.; Quintero-Angel, M. Effectiveness of vertical subsurface wetlands for iron and manganese removal from wastewater in drinking water treatment plants. Univ. Sci. 2019, 24, 135-163. [CrossRef]

46. Mustapha, H.I.; van Bruggen, J.J.A.; Lens, P.N.L. Fate of heavy metals in vertical subsurface flow constructed wetlands treating secondary treated petroleum refinery wastewater in Kaduna, Nigeria. Int. J. Phytoremediat. 2018, 20, 44-53. [CrossRef] [PubMed]

47. APHA, American Public Health Association; American Water Works Association; Water Environment Federation. Water Wastewater. In Standard Methods for the Examination of Water and Wastewater, 23rd ed.; American Water Works Association: Washington, DC, USA, 2002; Available online: https: / / www.awwa.org/Store/Product-Details/productId/65266295 (accessed on 26 April 2021).

48. Wei, X.; Viadero, R.C.; Buzby, K.M. Recovery of iron and aluminum from acid mine drainage by selective precipitation. Environ. Eng. Sci. 2005, 22, 745-755. [CrossRef]

49. Sandoval, L.; Marín-Muñiz, J.L.; Zamora-Castro, S.A.; Sandoval-Salas, F.; Alvarado-Lassman, A. Evaluation of wastewater treatment by microcosms of vertical subsurface wetlands in partially saturated conditions planted with ornamental plants and filled with mineral and plastic substrates. Int. J. Environ. Res. Public Health 2019, 16, 167. [CrossRef] [PubMed]

50. Conn, R.M.; Fiedler, F.R. Increasing Hydraulic Residence Time in Constructed Stormwater Treatment Wetlands with Designed Bottom Topography. Water Environ. Res. 2006, 78, 2514-2523. [CrossRef]

51. Ewemoje, O.E.; Sangodoyin, A.Y.; Adegoke, A. On the Effect of Hydraulic Retention Time and Loading Rates on Pollutant Removal in a Pilot Scale Wetland. J. Sustain. Dev. Stud. 2015, 8, 342-355.

52. Piñeyro, M.; Cabrera, J.; Quintans, F.; Tejera, M.; Chalar, G. Effects of hydraulic residence time in experimental constructed wetlands on wastewater treatment of a fish factory. Panam. J. Aquat. Sci. 2016, 11, 93-102.

53. Białowiec, A.; Albuquerque, A.; Randerson, P.F. The influence of evapotranspiration on vertical flow subsurface constructed wetland performance. Ecol. Eng. 2014, 67, 89-94. [CrossRef]

54. Van Tran, T.; Bui, Q.T.P.; Nguyen, T.D.; Le, N.T.H.; Bach, L.G. A comparative study on the removal efficiency of metal ions $\left(\mathrm{Cu}^{2+}\right.$, $\mathrm{Ni}^{2+}$, and $\mathrm{Pb}^{2+}$ ) using sugarcane bagasse-derived $\mathrm{ZnCl}_{2}{ }^{-}$activated carbon by the response surface methodology. Adsorpt. Sci. Technol. 2017, 35, 72-85. [CrossRef]

55. Shanshan, D.; Xiaofei, Y.; Zhang, J.; Zeyao, Y.; Yuanchun, Z.; Guoping, W.; Lianxi, S.; Chunguang, H. Bioconcentration and translocation of elements regulate plant responses to water-salt conditions in saline-alkaline wetlands. Environ. Exp. Bot. 2020, 183. [CrossRef]

56. Esmaeilzadeh, M.; Karbassi, A.; Moattar, F. Heavy metals in sediments and their bioaccumulation in Phragmites australis in the Anzali wetland of Iran. Chin. J. Oceanol. Limnol. 2016, 34, 810-820. [CrossRef]

57. Bonanno, G.; Vymazal, J.; Cirelli, G.L. Translocation, accumulation and bioindication of trace elements in wetland plants. Sci. Total Environ. 2018, 631-632, 252-261. [CrossRef] [PubMed]

58. Demchak, J.; Morrow, T.; Skousen, J. Treatment of acid mine drainage by four vertical flow wetlands in Pennsylvania. Geochem. Explor. Environ. Anal. 2001, 1,71-80. [CrossRef]

59. Chen, Y.; Wen, Y.; Zhou, Q.; Huang, J.; Vymazal, J.; Kuschk, P. Sulfate removal and sulfur transformation in constructed wetlands: The roles of filling material and plant biomass. Water Res. 2016, 102, 572-581. [CrossRef]

60. Balci, N.; Brunner, B.; Turchyn, A.V. Tetrathionate and elemental sulfur shape the isotope composition of sulfate in acid mine drainage. Front. Microbiol. 2017, 8. [CrossRef] [PubMed]

61. Saad, R.A.B.; Kuschk, P.; Wiessner, A.; Kappelmeyer, U.; Müller, J.A.; Köser, H. Role of plants in nitrogen and sulfur transformations in floating hydroponic root mats: A comparison of two helophytes. J. Environ. Manag. 2016, 181, 333-342. [CrossRef]

62. Zhang, X.; Jing, G.; Qinhong, H.; Xubo, G.; Cheng, L.; Meng, L.; Yanxin, W. Effects of Fe-rich acid mine drainage on percolation features and pore structure in carbonate rocks. J. Hydrol. 2020, 591, 125571. [CrossRef]

63. Rout, G.R.; Sahoo, S. Role of Iron in Plant Growth and Metabolism. Rev. Agric. Sci. 2015, 3, 1-24. [CrossRef]

64. Morkunas, I.; Wozniak, A.; Mai, V.C.; Rucinska-Sobkowiak, R.; Jeandet, P. The role of heavy metals in plant response to biotic stress. Molecules 2018, 23, 2320. [CrossRef]

65. Hassan, M.U.; Muhammad, A.; Muhammad, U.C.; Tang, H.; Babar, S.; Lorenzo, B.; Muhammad, N.; Adnan, R.; Aniqa, A.; Ying, L.; et al. The critical role of zinc in plants facing the drought stress. Agriculture 2020, 10, 396. [CrossRef]

66. Mousavi, S.R.; Shahsavari, M.; Rezaei, M. A general overview on manganese (Mn) importance for crops production. Aust. J. Basic Appl. Sci. 2011, 5, 1799-1803.

67. Stumm, W.; Morgan, J.J. Chemical Equilibria and Rates in Natural Waters. A Wiley-interscience publication. In Aquatic Chemistry, 3rd ed.; Wiley: Hoboken, NJ, USA, 1996; pp. 1-5. Available online: https:/ /www.wiley.com/en-us / Aquatic+Chemistry\%3A+ Chemical+Equilibria+and+Rates+in+Natural+Waters\%2C+3rd+Edition-p-9780471511854 (accessed on 26 April 2021).

68. Sheoran, A.S.; Sheoran, V. Heavy metal removal mechanism of acid mine drainage in wetlands: A critical review. Miner. Eng. 2006, 19, 105-116. [CrossRef]

69. Vymazal, J. Constructed wetlands for wastewater treatment. Encycl. Ecol. 2018, 45, 14-21. [CrossRef]

70. Almuktar, S.A.A.A.N.; Abed, S.N.; Scholz, M. Wetlands for wastewater treatment and subsequent recycling of treated effluent: A review. Environ. Sci. Pollut. Res. 2018, 25, 23595-23623. [CrossRef] [PubMed] 
71. Wang, M.; Zhang, D.Q.; Dong, J.W.; Tan, S.K. Constructed wetlands for wastewater treatment in cold climate-A review. J. Environ. Sci. 2017, 57, 293-311. [CrossRef] [PubMed]

72. Roongtanakiat, N.; Osotsapar, Y.; Yindiram, C. Effects of soil amendment on growth and heavy metals content in vetiver grown on iron ore tailings. Kasetsart J. Nat. Sci. 2008, 42, 397-406.

73. Zuo, Y.; Zhang, F. Soil and crop management strategies to prevent iron deficiency in crops. Plant Soil 2011, 339, 83-95. [CrossRef]

74. Brosnan, J.; Brosnan, M. 5th Amino Acid Assessment Workshop-The Sulfur-Containing Amino Acids: An Overview. J. Nutr. 2006, 136, 16365-16405. [CrossRef]

75. Colovic, M.B.; Vasic, V.M.; Djuric, D.M.; Krstic, D.Z. Sulphur-containing Amino Acids: Protective Role Against Free Radicals and Heavy Metals. Curr. Med. Chem. 2018, 25. [CrossRef] [PubMed]

76. Wilkins, A.D. The Measurement of Tolerance to Edaphic Factors by Means of Root Growth. New Phytol. 1978, 80, 623-633. [CrossRef]

77. Truong, P.; Danh, L.T. The Vetiver System for Improving Water Quality, 2nd ed.; Vetiver Network International: Brisbane, Australia, 2015.

78. Truong, P.; Tran, M. Workshop 3 Vetiver Grass Technology for Rehabilitation of Mining Wastes and Tailings. 2014, pp. 1-20. Available online: www.vetiver.org (accessed on 15 January 2021).

79. Roongtanakiat, N.; Sanoh, S. Phytoextraction of Zinc, Cadmium and Lead from contaminated soil by vetiver grass. Kasetsart J. Nat. Sci. 2011, 45, 603-612.

80. Tripathi, R.D.; Tripathi, P.; Sanjay, D.; Amit, K.; Aradhana, M.; Puneet, C.; Gareth, J.N.; Chandra, S. Roles for root iron plaque in sequestration and uptake of heavy metals and metalloids in aquatic and wetland plants. Metallomics 2014, 6, 1789-1800. [CrossRef]

81. Adamczyk-Szabela, D.; Markiewicz, J.; Wolf, W.M. Heavy metal uptake by herbs. IV. Influence of soil pH on the content of heavy metals in Valeriana officinalis L. Water Air. Soil Pollut. 2015, 226. [CrossRef]

82. Watmough, S.A.; Eimers, M.C.; Dillon, P.J. Manganese cycling in central Ontario forests: Response to soil acidification. Appl. Geochem. 2007, 22, 1241-1247. [CrossRef]

83. Millaleo, R.; Reyes-Díaz, M.; Ivanov, A.G.; Mora, M.L.; Alberdi, M. Manganese as essential and toxic element for plants: Transport, accumulation and resistance mechanisms. J. Soil Sci. Plant Nutr. 2010, 10, 476-494. [CrossRef]

84. Yadava, N. Effect of phosphate and manganese application on manganese pools in soil and its uptake in wheat (Triticum aestivum L.). J. Appl. Biosci. 2015, 41, 137-143.

85. Teng-Hao-Bo, D.; Van der Ent, A.; Ye-Tao, T.; Thibault, S.; Echevarria, E.; Jean-Louis, M.; Rong-Liang, Q. Nickel hyperaccumulation mechanisms: A review on the current state of knowledge. Plant Soil. 2018, 423. [CrossRef]

86. Soil, C.; Gunwal, I.; Singh, L.; Mago, P. Comparison of Phytoremediation of Cadmium and Nickel from Contaminated Soil by Vetiveria zizanioides L. Int. J. Sci. Res. Publ. 2014, 4, 1-7.

87. Suelee, A.L.; Hasan, S.N.M.S.; Kusin, F.M.; Yusuff, F.M.; Ibrahim, Z.Z. Phytoremediation Potential of Vetiver Grass (Vetiveria zizanioides) for Treatment of Metal-Contaminated Water. Water. Air. Soil Pollut. 2017, 228. [CrossRef]

88. Roy, B.; Bhadra, S. Effects of toxic levels of aluminium on seedling parameters of rice under hydroponic culture. Rice Sci. 2014, 21, 217-223. [CrossRef]

89. Wang, L.P.; Josiane, P.; Seiji, M.; Katsunori, O.; Gjergj, D.; Tatsuki, N.; Toyohisa, F. Selective precipitation of copper and zinc over iron from acid mine drainage by neutralization and sulfidization for recovery. Int. J. Soc. Mater. Eng. Resour. 2014, 20, 136-140. [CrossRef]

90. Singh, R.; Singh, D.P.; Kumar, N.; Bhargava, S.K.; Barman, S.C. Accumulation and translocation of heavy metals in soil and plants from fly ash contaminated area. J. Environ. Biol. 2010, 31, 421-430.

91. Lizama Allende, K.; Fletcher, T.D.; Sun, G. The effect of substrate media on the removal of arsenic, boron and iron from an acidic wastewater in planted column reactors. Chem. Eng. J. 2012, 179, 119-130. [CrossRef]

92. Geddie, A.W.; Hall, S.G. An introduction to copper and zinc pollution in macroalgae: For use in remediation and nutritional applications. J. Appl. Phycol. 2019, 31, 691-708. [CrossRef]

93. Shelef, O.; Gross, A.; Rachmilevitch, S. Role of plants in a constructed Wetland: Current and new perspectives. Water 2013, 5, 405-419. [CrossRef]

94. Cortes-Esquivel, J.A.; Giácoman-Vallejos, G.; Barceló-Quintal, I.D.; Méndez-Novelo, R.; Ponce-Caballero, M.C. Heavy Metals Removal from Swine Wastewater Using Constructed Wetlands with Horizontal Sub-Surface Flow. J. Environ. Prot. 2012, 3 , 871-877. [CrossRef]

95. Biyada, S.; Merzouki, M.; Elkarrach, K.; Benlemlih, M. Spectroscopic characterization of organic matter transformation during composting of textile solid waste using UV-Visible spectroscopy, Infrared spectroscopy and X-ray diffraction (XRD). Microchem. J. 2020, 159, 105314. [CrossRef]

96. Sharma, A.; Ganguly, R.; Gupta, A.K. Spectral characterization and quality assessment of organic compost for agricultural purposes. Int. J. Recycl. Org. Waste Agric. 2019, 8, 197-213. [CrossRef]

97. Lee, J.; Kwag, H.; Ra, C.S. Influence of Compost Recycling and Magnesium Supplement on Physical and Chemical Traits of Animal Manure Compost. J. Anim. Sci. Technol. 2010, 52, 513-519. [CrossRef]

98. Grigatti, M.; Boanini, E.; Mancarella, S.; Simoni, A.; Centemero, M.; Veeken, A.H.M. Phosphorous extractability and ryegrass availability from bio-waste composts in a calcareous soil. Chemosphere 2017, 174, 722-731. [CrossRef] [PubMed] 
99. Shun-hui, Y.; Hong-ping, D.; Bo, Z.; Zheng-xue, L.; Jun-jie, L.; Li, S.; Jie, P.; Lianqi, H.; Jun-sheng, Q. Physiological Response of Vetiveria Zizanioides to Cadmium Stress Revealed by Fourier Transform Infrared Spectroscopy. Spectrosc. Lett. 2017. [CrossRef]

100. RoyChowdhury, A.; Mukherjee, P.; Panja, S.; Datta, R.; Christodoulatos, C.; Sarkar, D. Evidence for Phytoremediation and Phytoexcretion of NTO from Industrial Wastewater by Vetiver Grass. Molecules 2020, 26, 74. [CrossRef] [PubMed]

101. Bahri, S.; Raharjo, T.T.; Ambarwati, Y.; Nurhasanah, Y. Isolation and Identification of Terpenoid Compound from Vetiver GrassRoot (Vetiveria zizanioides Stapf) as a Repellent against Termite (Cyrptotermes sp.) through Bioactivity Assay. J. Phys. Conf. Ser. 2021, 1751. [CrossRef]

102. Masindi, V. A novel technology for neutralizing acidity and attenuating toxic chemical species from acid mine drainage using cryptocrystalline magnesite tailings. J. Water Process Eng. 2016, 10, 67-77. [CrossRef]

103. Kiiskila, D.; Sarkar, D.; Panja, S.; Sahi, V.; Datta, R. Remediation of acid mine drainage-impacted water by vetiver grass (Chrysopogon zizanioides): A multiscale long-term study. Ecolog. Eng. 2019, 129, 97-108. [CrossRef] 